Page 1 of 2 Proj.

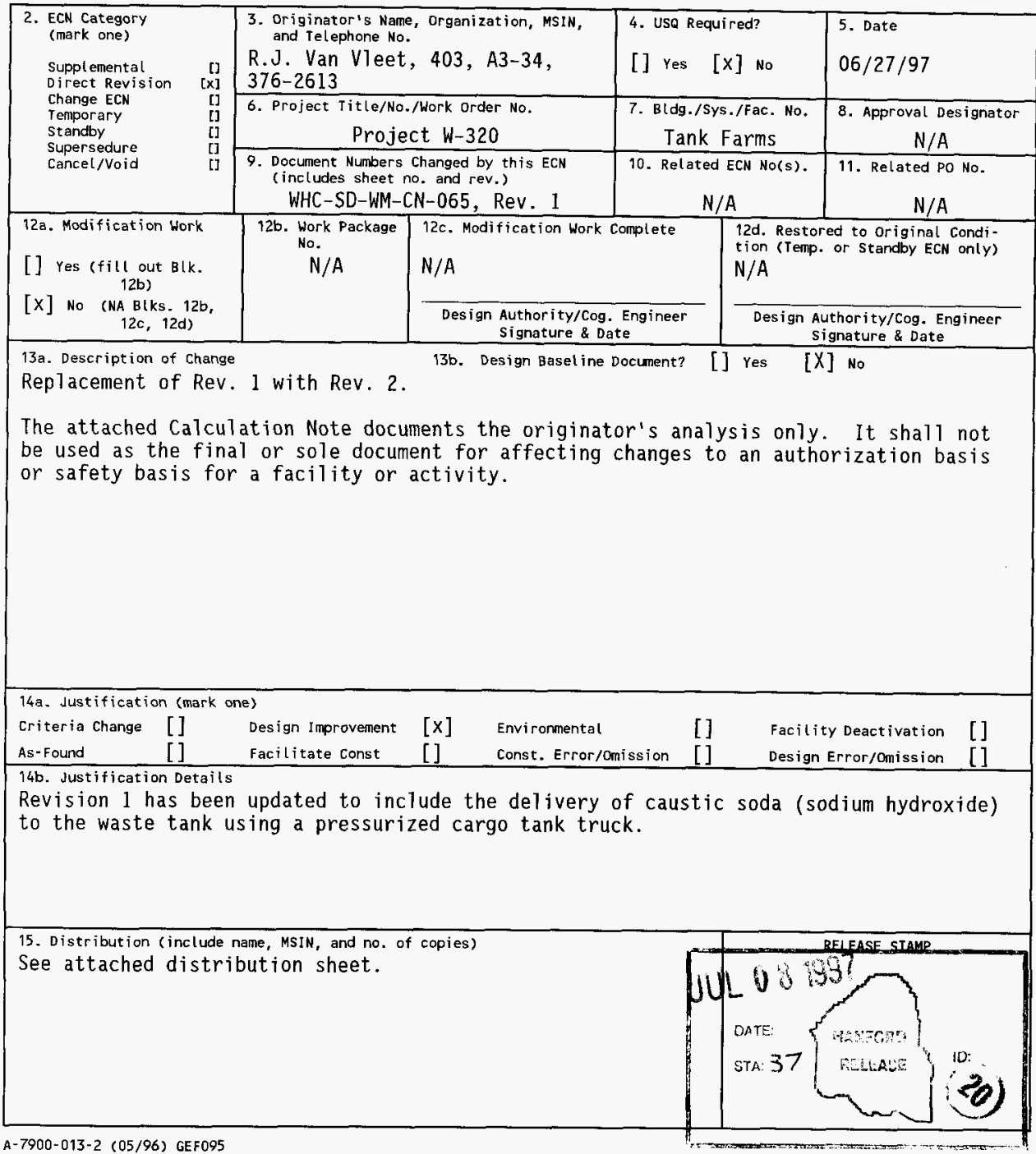




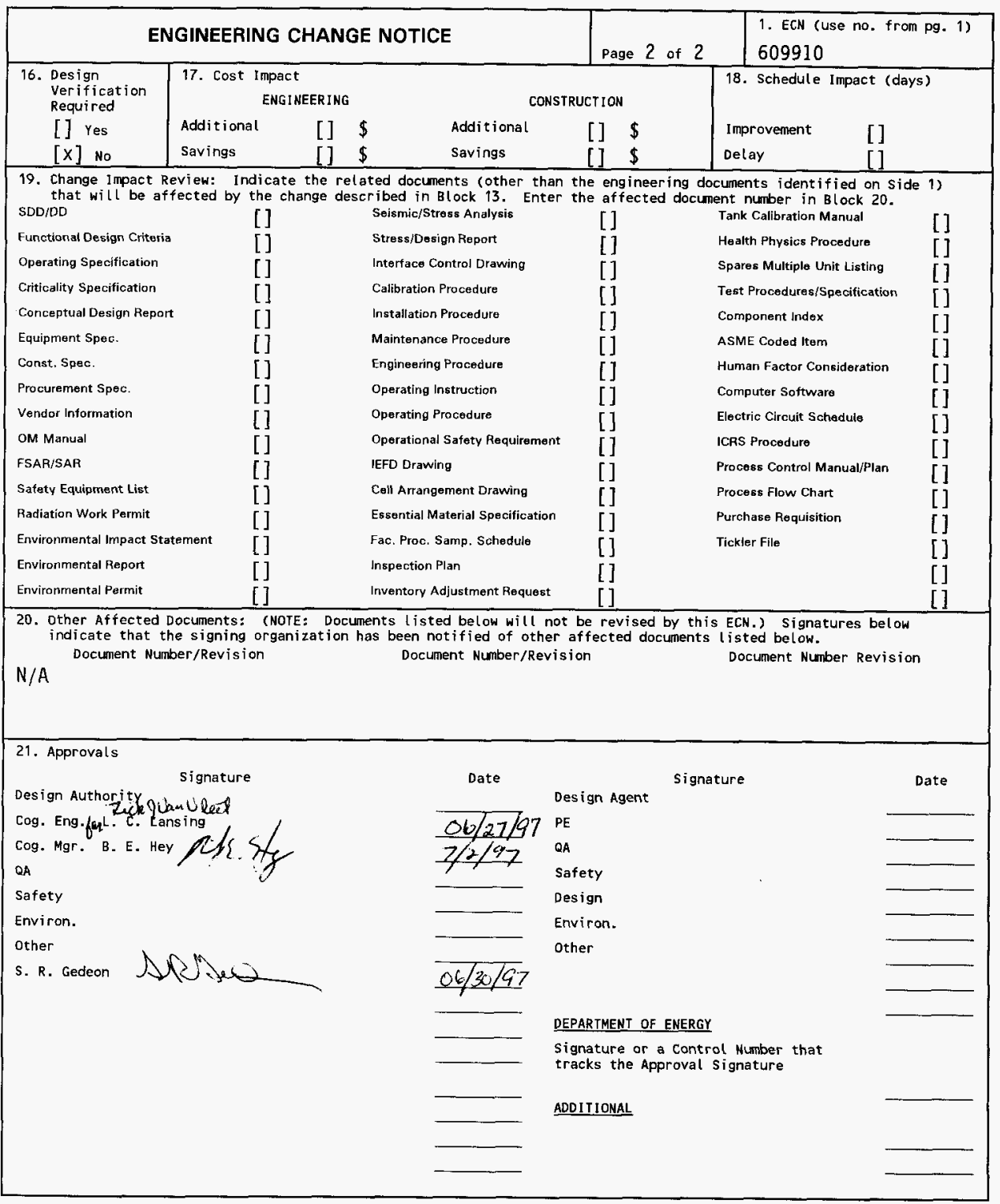




\title{
Consequence Analysis of a NaOH Solution Spray Release during Addition to Waste Tank
}

\author{
L. C. Lansing
}

H \& R Technical Associates, Richland, WA 99352

for

R. J. Van Vleet

Fluor Daniel Northwest Inc., Richland, WA 99352

U.S. Department of Energy Contract DE-AC06-96RL13200

EDT/ECN: $609910 \quad$ UC: 510

Org Code: 403 Charge Code: E34272/P3YA00

B\&R Code: EW3130010 Total Pages: ${ }_{-59}^{59} 63$

Key Words: caustic, $\mathrm{NaOH}$, pH adjustment, spray leak, sodium hydroxide, toxic consequences

Abstract: Toxicological consequences are presented for 3 postulated accidents involving caustic soda (sodium hydroxide) addition to a waste tank to adjust the tank waste $\mathrm{pH}$. These are: spray from the skid mounted delivery system, spray from a cargo tank truck, and rupture of a cargo tank truck. Consequences for the onsite and offsite receptor are calculated.

TRADEMARK DISCLAIMER. Reference herein to any specific commercial product, process, or service by trade name, trademark, manufacturer, or otherwise, does not necessarily constitute or imply its endorsement, recommendation, or favoring by the United States Government or any agency thereof or its contractors or subcontractors.

Printed in the United States of America. To obtain copies of this document, contact: Document Control Services, P.O. Box 950, Mailstop H6-08, Richland WA 99352, Phone (50́9) 372-2420;

Fax (509) 376-4989.
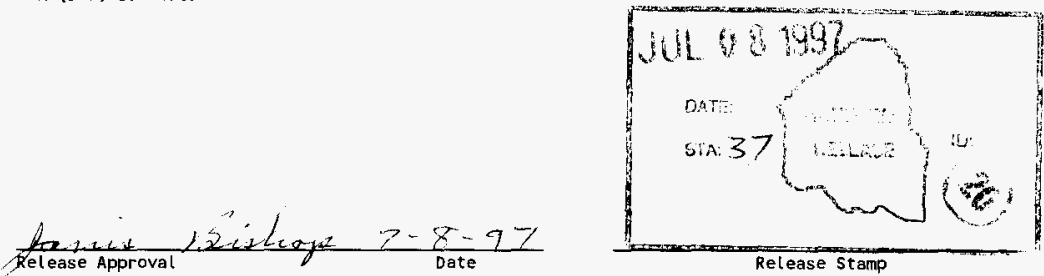

\section{Approved for Public Release}




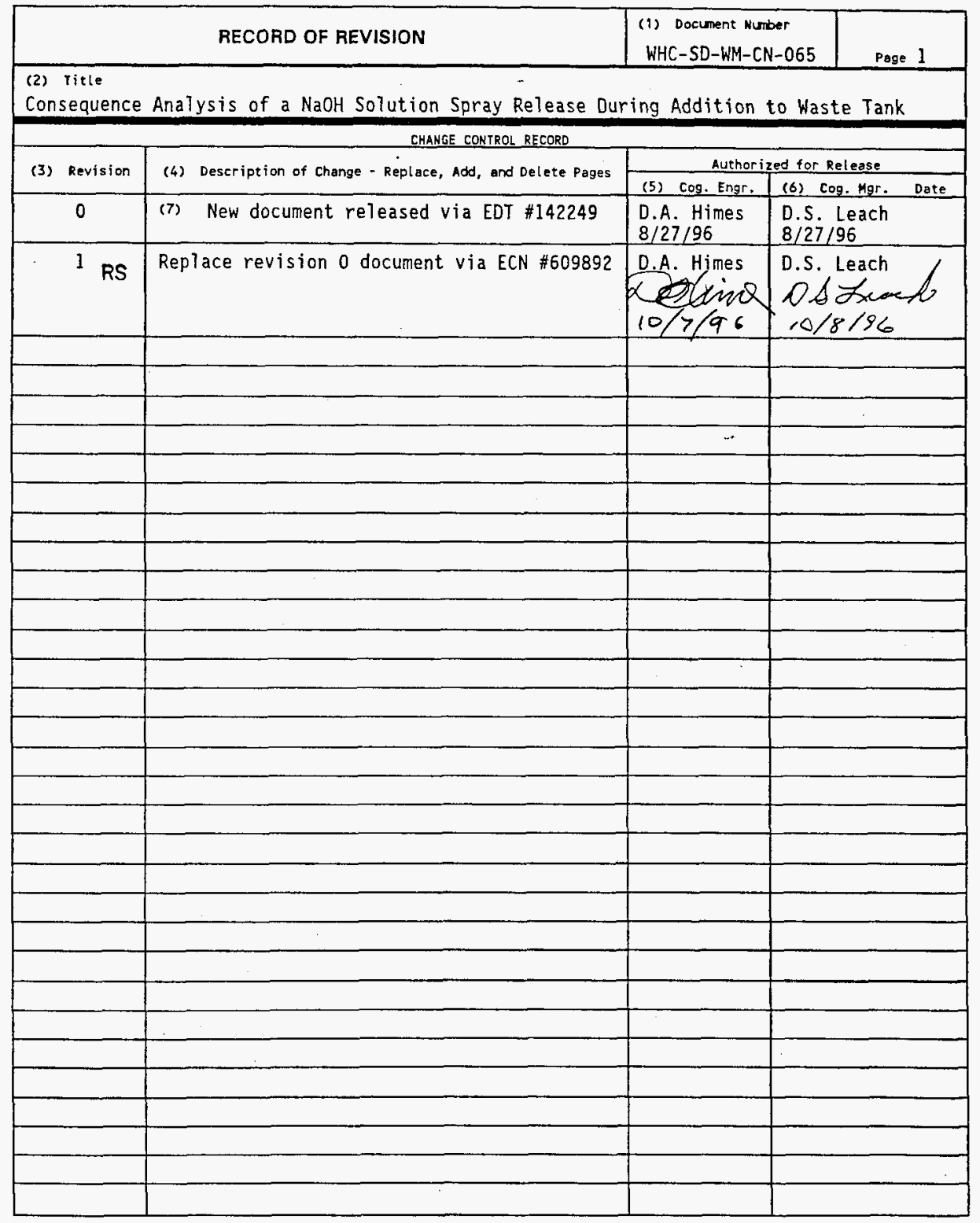




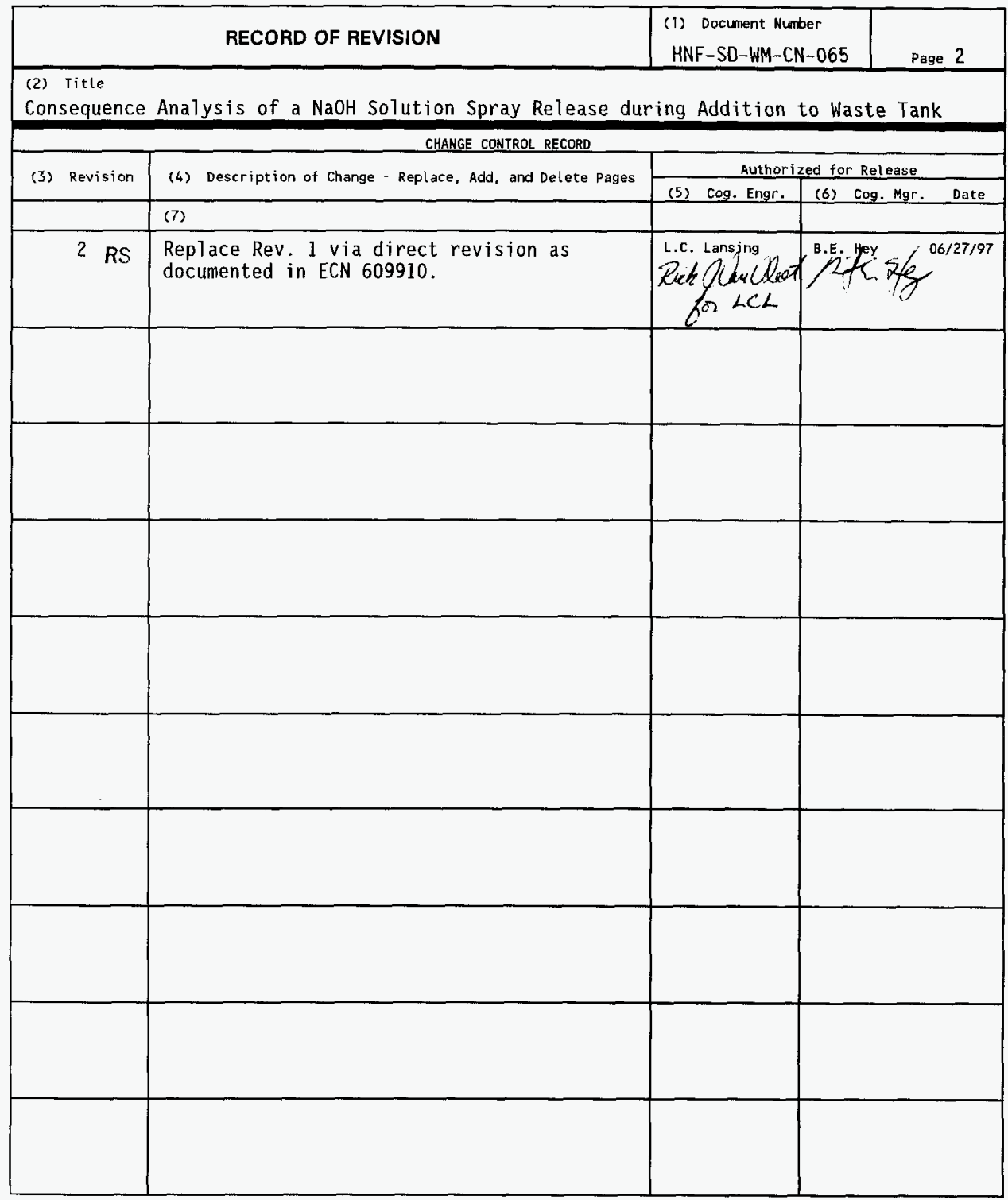




\section{CONSEQUENCE ANALYSIS OF A NaOH SOLUTION SPRAY RELEASE DURING ADDITION TO WASTE TANK}

\subsection{PURPOSE}

Aqueous sodium hydroxide $(\mathrm{NaOH})$ solutions are added as needed to Hanford waste tanks to adjust waste $\mathrm{pH}$ so as to minimize corrosion in the tanks. Sodium hydroxide is either (1) procured from an offsite vendor and transported in 15,140-L (4,000-gal) tanker trucks to the tank farms or (2) mixed on site. The caustic solution may be as strong as $19 \mathrm{M}(50 \mathrm{wt} \%)$. The solution may be transferred into a given tank by a mixer pump or directly through an available riser (with a fitting). The lightest equipment considered to be suitable for $\mathrm{NaOH}$ solution transport is 25.4-mm (1-in.) schedule 10 commercial steel pipe with a wall thickness of $2.77 \mathrm{~mm}(0.109 \mathrm{in}$.$) . The largest pipe or hose$ considered is $50.8-\mathrm{mm}$ (2-in.) cross linked polyethylene hose with a wall thickness of $10 \mathrm{~mm}(25 / 64 \mathrm{in}$.). The maximum pressure the system can be subjected to is $863 \mathrm{kPa}$ (125 psig) the maximum pressure that can be delivered by the air supply system in the tank farms. The highest temperature at which the tank truck is loaded is $49^{\circ} \mathrm{C}\left(120^{\circ} \mathrm{F}\right)$.

This calculation note analyzes (1) a crack in a caustic skid system (consisting of a 208-L (55-gal) drum, hard pipe, hose, and a pump); (2) a crack in the cargo tank; and (3) a sudden failure of the cargo tank.

A pressurized spray leak of caustic solution during a transfer to a waste tank could disperse a significant amount of respirable sodium hydroxide particles. These particles could cause potentially significant onsite consequences. This analysis will (1) estimate the maximum $\mathrm{NaOH}$ air concentrations at the onsite and site boundary receptor locations and (2) develop and analyze precautions which could be taken to mitigate the onsite consequences should a spray leak develop. No radioactive materials are associated with this event. 


\subsection{ACCIDENT DESCRIPTION}

\subsection{Spray from Skid System Failure}

A pressure of $863 \mathrm{kPa}$ (125 psig) is not expected to be able to cause schedule 10 steel pipe to fail. Schedule 10 steel pipe is rated for a working pressure of about $5.86 \mathrm{MPa}$ ( $850 \mathrm{psig}$ ) for temperatures less than $343.3{ }^{\circ} \mathrm{C}$ $\left(650{ }^{\circ} \mathrm{F}\right)$ (Chemetron 1969). The most likely cause of a spray release is considered to be a loose connection, or possibly a cracked circumferential weld joining the pipe to a flange or fitting due to repetitive mechanical stress on the pipe. In the case of a loose fitting, the leak could extend around the full circumference of the sealing surface. The depth (path length) of the opening in such a case, however, would be much greater than the wall thickness of the pipe and so would exhibit a much lower leak rate due to friction losses. Polyethylene is not stiff enough to maintain the fine crack width associated with an atomizing spray over a crack length sufficient to produce a significant leak rate. A split in the polyethylene hose large enough to cause a significant release rate would therefore produce a stream (with little production of small particles) rather than a fine spray. The worst case circumferential crack in a pipe weld able to maintain the narrow width associated with a fine aerosol spray is normally assumed to extend a distance around the pipe equal to one pipe diameter (inside).

The maximum spray Teak was therefore assumed to be a crack with a minimum depth equal to the lightest (schedule 10) pipe wall thickness of $2.77 \mathrm{~mm}(0.109 \mathrm{in.})$ and a maximum length equal to one pipe diameter, i.e., $25.4 \mathrm{~mm}$ ( $1 \mathrm{in.)}$. The width of the crack was optimized to produce the highest respirable particle fraction using the SPRAY Code (Hey and Leach 1994).

\subsection{Spray from Crack in the Cargo Tank}

A procedure not analyzed in the 208-L (55-gal) drum and skid system analysis involves a cargo tank attached to an air compressor. The compressor pressurizes the cargo tank, pushing the sodium hydroxide out, and through the connected hose leading into the underground waste tank.

A crack in the cargo tank could create a spray leak of $\mathrm{NaOH}$ solution. A crack could develop in the cargo tank for several reasons, including corrosion, stress, fatigue, and impact. New cargo tanks are written to DOT specification 406, 407, or 412. However, older cargo tanks are written to DOT specifications 306,307 , or 312 . The minimum cargo tank wall thickness under these specifications is 0.100 inches. The cargo tank is considered to be pressurized up to $863 \mathrm{kPa}$ (125 psig), the maximum available plant air pressure. Since the pressurization of the cargo tank is achieved by use of compressed air, the pressure inside the cargo tank will not drop upon formation of a spray leak. The highest temperature at which the cargo tank is loaded is $49^{\circ} \mathrm{C}\left(125^{\circ} \mathrm{F}\right)$.

A spray leak could also develop in the truck transfer piping, due to a loose fitting or crack. This possibility is bounded by those listed above, because the crack in the piping is limited in size (optimum spray typically occurs when the crack is equal to the diameter of the pipe). 


\subsection{Sudden Failure of the Cargo Tank}

A significant release could also result from sudden failure of the cargo tank. A sudden cargo tank failure could result from rapid propagation of an al ready existing crack, internal overpressurization of the cargo tank, or an external impact to the cargo tank.

An existing stress or corrosion crack could propagate beyond the critical crack length and result in a sudden cargo tank failure. Although stainless steel 316 (typically used in building cargo tanks) is not subject to sudden failure from rapid propagation of an already existing crack, this potential event sequence is discussed here to address the possible use of cargo tanks constructed of materials other than stainless steel 316 . Since the pressure inside the cargo tank would remain high, the size of the crack would increase slowly until the critical crack length were reached, at which point the size of the crack would increase rapidly such that the internal pressure is relieved almost instantaneously.

A second mechanism for sudden cargo tank failure would be overpressurization of the cargo tank beyond its structural capacity. The resulting failure of the cargo tank could be expected to be violent and near instantaneous.

In addition to an already existing crack and overpressurization of the cargo tank, an object impact to the cargo tank could cause sudden cargo tank faijure. Heavy equipment (cranes, earth movers, etc.) and light vehicles (trucks) are the most likely source of impacts to the cargo tank. If such an impact were to cause the failure of the cargo tank, the internal cargo tank pressure would be relieved almost instantaneously. 


\subsection{TRANSPORT ASSUMPTIONS}

For a ground level release the onsite receptor is normally assumed to be at a distance of $100 \mathrm{~m}$ in the worst direction (WHC 1988). The site boundary receptor for purposes of this analysis is located at the site boundary or the near bank of the Columbia River, whichever is closer, in the worst direction. No receptor evacuation was assumed.

Acute 99.5 percentile ground level release dispersion factors $(x / Q)$ have been generated for the Hanford tank farms using the GXQ code (Hey 1994) at each of the 16 sectors at $100 \mathrm{~m}$ and at the site boundary or the near bank of the Columbia River.

\subsection{Spray Leaks}

Since maximum air concentrations are the primary concern for toxic releases, no plume meander was assumed. The resulting $X / Q$ s are reported in WHC-SD-WM-SARR-016 Rev 2 (Van Keuren 1996) as $3.41 \times 10^{-2} \mathrm{~s} / \mathrm{m}^{3}$ ons ite (100 m E) and $2.83 \times 10^{-5} \mathrm{~s} / \mathrm{m}^{3}$ at the site boundary $(8.76 \mathrm{~km} \mathrm{~N})$.

In the case of a liquid spray release, care must be taken to account for evaporation during transit when estimating the small particle ("respirable") fraction. Particles less than about $10 \mu \mathrm{m}$ tend to remain suspended in the air for long distances whereas particles larger than $10 \mu \mathrm{m}$ released from a nonelevated source tend to fall out within the first 50 to $100 \mathrm{~m}$ of trave1. (The term "respirable fraction" is often used in reference to particles less than $10 \mu \mathrm{m}$ because this is the size range which can reach the lower lung.) The size of the liquid particles will decrease in transit due to evaporation of the liquid component finally leaving only a smaller particle of the solid material which had been in solution in the liquid. The initial diameter, $D_{r}$, of a solution particle with a solid fraction $f_{s}$ which will evaporate to a particle with a diameter of $10 \mu \mathrm{m}$ is given by (Hey and Leach 1995)

$$
D_{T}=\frac{10 \mu \mathrm{m}}{f_{S}^{\frac{1}{3}}}
$$

The resulting initial particle diameters are shown in Table 1 along with solution viscosity and density (Perry and Green 1984) for a range of solid fractions of $\mathrm{NaOH}$ in water. The leak rate and atomization efficiency increase with decreasing viscosity and hence increasing temperature. The high end of the temperature range for this liquid $\left(50^{\circ} \mathrm{C}\right)$ is therefore assumed. 
Table 1: Concentration dependent parameters for caustic soda $(\mathrm{NaOH})$ solutions at $50^{\circ} \mathrm{C}$.

\begin{tabular}{|c|c|c|c|}
\hline$\% \mathrm{NaOH}$ & $\begin{array}{c}\text { Density } \\
\left(\mathrm{g} / \mathrm{cm}^{3}\right)\end{array}$ & $\begin{array}{c}\text { Viscosity } \\
\text { (centipoise) }\end{array}$ & $\mathrm{D}_{r}(\mu \mathrm{m})$ \\
\hline 5 & 1.041 & 0.80 & 27.1 \\
\hline 10 & 1.094 & 0.96 & 21.5 \\
\hline 12 & 1.116 & 1.1 & 20.3 \\
\hline 15 & 1.148 & 1.3 & 18.8 \\
\hline 20 & 1.202 & 1.9 & 17.1 \\
\hline 30 & 1.309 & 4.4 & 14.9 \\
\hline 40 & 1.410 & 8.5 & 13.6 \\
\hline 50 & 1.504 & 14.3 & 12.6 \\
\hline
\end{tabular}

It is conservatively assumed here that the liquid fraction of the spray evaporates very quickly. In reality the initial large size of the "respirable" particles would cause rapid initial fallout.

\subsection{Sudden Failure of the Cargo Tank}

Since a sudden cargo tank failure release occurs in a very short period of time it can be modeled as a puff release. The puff release $X / Q$ value for the onsite receptor is $9.85 \times 10^{-3} / \mathrm{m}^{3}$ (Van Keuren 1996). The puff release $x / Q$ value for the offsite receptor is $1.14 \times 10^{-7} / \mathrm{m}^{3}$ (Van Keuren 1996). 


\subsection{SOURCE TERM}

\subsection{Spray from Skid System Failure}

The SPRAY Code version 3.0 (Hey and Leach 1995) was used to calculate leak rates and small particle fractions for the assumed break (a crack with a minimum depth equal to $2.77 \mathrm{~mm}[0.109$ in. $]$ and a maximum length equal to $25.4 \mathrm{~mm}$ [ $1 \mathrm{in.]})$ in the liquid containment boundary. The crack width was optimized to maximize the release rate of particles with an initial size less than or equal to the size given as $D_{r}$ in Table 1 .

At low solution concentrations, the viscosity is low (approaching that of water) so that friction losses in the crack are low and solution release rates are relatively high. The $\mathrm{NaOH}$ release rate is low, however, due to the low concentration. As concentration increases, the $\mathrm{NaOH}$ respirable release rate initially stays fairly constant due to the competing effects of increasing concentration and decreasing initial particle size range due to effects of evaporation. However as concentration is increased further, the increase in solution viscosity causes a rapidly decreasing flow rate. There is also an added effect due to a transition from turbulent flow at low viscosity to 1 aminar flow at higher viscosities. It is expected, therefore, that the maximum small particle $\mathrm{NaOH}$ release rate will occur at some optimum solution concentration. A parametric study was performed using the SPRAY Code to determine this optimum solution concentration within the expected range of $5 \%$ to $50 \% \mathrm{NaOH}$ to be used for tank additions. The small particle release rate was therefore calculated over a range of $\mathrm{NaOH}$ concentrations with the results shown in Table 2. Standard roughness and flow parameters for stee] pipe were assumed as documented in the SPRAY Code output files shown in Attachment 1. For the cases where critical flow developed in the crack, friction factors for laminar flow were assumed for conservatism.

Table 2: Solution spray release parameters.

\begin{tabular}{|c|c|c|c|c|}
\hline$\% \mathrm{NaOH}$ & $\begin{array}{c}\text { Optimum } \\
\text { Crack } \\
\text { Width (m) }\end{array}$ & $\begin{array}{c}\text { Flow } \\
\text { Type }\end{array}$ & $\begin{array}{c}\text { Respirable } \\
\text { Fraction }\end{array}$ & $\begin{array}{c}\text { Respirable } \\
\text { NaOH Release } \\
\text { Rate (g/s) }\end{array}$ \\
\hline 5 & $9.99 \mathrm{E}-05$ & Turbulent & $7.10 \mathrm{E}-02$ & 0.193 \\
\hline 10 & $9.81 \mathrm{E}-05$ & Turbulent & $3.76 \mathrm{E}-02$ & 0.204 \\
\hline 12 & $4.60 \mathrm{E}-05$ & Critical & $4.12 \mathrm{E}-01$ & 1.68 \\
\hline 15 & $4.68 \mathrm{E}-05$ & Critical & $3.00 \mathrm{E}-01$ & 1.53 \\
\hline 20 & $5.34 \mathrm{E}-05$ & Laminar & $1.38 \mathrm{E}-01$ & 1.07 \\
\hline 30 & $7.77 \mathrm{E}-05$ & Laminar & $2.19 \mathrm{E}-02$ & 0.384 \\
\hline 40 & $1.05 \mathrm{E}-04$ & Laminar & $5.10 \mathrm{E}-03$ & 0.166 \\
\hline 50 & $1.35 \mathrm{E}-04$ & Laminar & $1.55 \mathrm{E}-03$ & 0.0840 \\
\hline
\end{tabular}

As indicated in the table, the maximum small particle $\mathrm{NaOH}$ release rate corresponded to a solution concentration of $12 \%$. 


\subsection{Spray Leak from Crack in the Cargo Tank}

The SPRAY Code version 3.0 (Hey and Leach 1994) was used to calculate leak rates and small particle fractions for various crack lengths in order to find the minimum crack length required to produce offsite consequences. The crack depth is $2.54 \mathrm{~mm}(0.10 \mathrm{in}$.) based on the cargo tank wall thickness. The crack width was optimized to maximize the release rate of particles with an initial size less than or equal to the size given as $D_{r}$ in Table 1.

The caustic spray leak analyzed here has been assigned a frequency of occurrence in the anticipated range $\left(1 \times 10^{-2}\right.$ to 1.0 per year $)$. The risk guidelines for onsite and site boundary receptors for this frequency range are ERPG-1 and PEL-TWA. Both of these criteria are $2 \mathrm{mg} / \mathrm{m}^{3}$ for $\mathrm{NaOH}$ (Van Keuren 1996).

To calculate the respirable release rate which reșults in offsite consequences, the offsite concentration 1 imit of $2 \mathrm{mg} / \mathrm{m}^{3}$ is divided by the offsite $x / Q$, as follows:

$$
\begin{aligned}
\mathrm{NaOH} \text { Respirable Release Rate } & =\left(2 \mathrm{mg} / \mathrm{m}^{3}\right) /\left(2.83 \mathrm{E}-05 \mathrm{~s} / \mathrm{m}^{3}\right) \\
& =7.07 \mathrm{E}+04 \mathrm{mg} / \mathrm{s} .
\end{aligned}
$$

The sodium hydroxide respirable release rate is divided by the sodium hydroxide solution concentration in order to obtain the necessary respirable release rate for the overall solution, see Table 3 .

Table 3. Calculation of Respirable Release Rates Required to Exceed Offsite Guidelines.

\begin{tabular}{|c|c|c|}
\hline$\% \mathrm{NaOH}$ & $\begin{array}{c}\text { NaOH Respirable } \\
\text { Release Rate (mg/s) }\end{array}$ & $\begin{array}{c}\text { Respirable Release } \\
\text { Rate (mg/s) }\end{array}$ \\
\hline 5 & $7.07 \mathrm{E}+04$ & $1.41 \mathrm{E}+06$ \\
\hline 8 & $7.07 \mathrm{E}+04$ & $8.83 \mathrm{E}+05$ \\
\hline 9 & $7.07 \mathrm{E}+04$ & $7.85 \mathrm{E}+05$ \\
\hline 10 & $7.07 \mathrm{E}+04$ & $7.07 \mathrm{E}+05$ \\
\hline 11 & $7.07 \mathrm{E}+04$ & $6.42 \mathrm{E}+05$ \\
\hline 12 & $7.07 \mathrm{E}+04$ & $5.89 \mathrm{E}+05$ \\
\hline 13 & $7.07 \mathrm{E}+04$ & $5.44 \mathrm{E}+05$ \\
\hline 15 & $7.07 \mathrm{E}+04$ & $4.71 \mathrm{E}+05$ \\
\hline 20 & $7.07 \mathrm{E}+04$ & $3.53 \mathrm{E}+05$ \\
\hline 30 & $7.07 \mathrm{E}+04$ & $2.36 \mathrm{E}+05$ \\
\hline 40 & $7.07 \mathrm{E}+04$ & $1.77 \mathrm{E}+05$ \\
\hline 50 & $7.07 \mathrm{E}+04$ & $1.41 \mathrm{E}+05$ \\
\hline
\end{tabular}


A parametric study was performed using the SPRAY Code to determine the minimum crack length necessary to achieve offsite consequences of solution concentrations within a range of $5 \%$ to $50 \% \mathrm{NaOH}$. Standard roughness and flow parameters for steel pipe were assumed as documented in the SPRAY Code output files shown in Attachment 1 . For the cases where critical flow developed in the crack, friction factors for laminar flow were assumed for conservatism. The results of the parametric study are shown in Table 4 .

Table 4. Solution Spray Release Parameters.

\begin{tabular}{|c|c|c|c|c|c|c|}
\hline $\begin{array}{c}\% \\
\mathrm{NaOH}\end{array}$ & $\begin{array}{c}\text { Minimum } \\
\text { Length } \\
(\mathrm{m})\end{array}$ & $\begin{array}{c}\text { Optimum } \\
\text { Width } \\
(\mathrm{m})\end{array}$ & $\begin{array}{c}\text { Crack } \\
\text { Type }\end{array}$ & $\begin{array}{c}\text { Flow } \\
\text { Fraction }\end{array}$ & $\begin{array}{c}\text { Respirable } \\
\text { Rate (g/s) }\end{array}$ & $\begin{array}{c}\text { Respirable } \\
\text { NaOH Re1ease } \\
\text { (g/s) }\end{array}$ \\
\hline 5 & 1.30 & $5.19 \mathrm{E}-05$ & Turbulent & $6.85 \mathrm{E}-01$ & $1.42 \mathrm{E}+03$ & $7.10 \mathrm{E}+01$ \\
\hline 8 & 1.07 & $4.68 \mathrm{E}-05$ & Critical & $5.96 \mathrm{E}-01$ & $8.97 \mathrm{E}+02$ & $7.18 \mathrm{E}+01$ \\
\hline 9 & 1.04 & $4.59 \mathrm{E}-05$ & Critical & $5.52 \mathrm{E}-01$ & $7.89 \mathrm{E}+02$ & $7.10 \mathrm{E}+01$ \\
\hline 10 & 1.02 & $4.48 \mathrm{E}-05$ & Critical & $5.35 \mathrm{E}-01$ & $7.22 \mathrm{E}+02$ & $7.22 \mathrm{E}+01$ \\
\hline 11 & 1.09 & $4.49 \mathrm{E}-05$ & Critical & $4.59 \mathrm{E}-01$ & $6.57 \mathrm{E}+02$ & $7.23 \mathrm{E}+01$ \\
\hline 12 & 1.04 & $4.48 \mathrm{E}-05$ & Critical & $4.41 \mathrm{E}-01$ & $6.01 \mathrm{E}+02$ & $7.21 \mathrm{E}+01$ \\
\hline 13 & 1.19 & $4.60 \mathrm{E}-05$ & Critical & $3.52 \mathrm{E}-01$ & $5.55 \mathrm{E}+02$ & $7.22 \mathrm{E}+01$ \\
\hline 15 & 1.12 & $4.48 \mathrm{E}-05$ & Laminar & $3.32 \mathrm{E}-01$ & $4.76 \mathrm{E}+02$ & $7.14 \mathrm{E}+01$ \\
\hline 20 & 1.57 & $5.13 \mathrm{E}-05$ & Laminar & $1.53 \mathrm{E}-01$ & $3.56 \mathrm{E}+02$ & $7.12 \mathrm{E}+01$ \\
\hline 30 & 4.37 & $7.42 \mathrm{E}-05$ & Laminar & $2.47 \mathrm{E}-02$ & $2.37 \mathrm{E}+02$ & $7.11 \mathrm{E}+01$ \\
\hline 40 & 10.06 & $1.01 \mathrm{E}-04$ & Laminar & $5.70 \mathrm{E}-03$ & $1.77 \mathrm{E}+02$ & $7.08 \mathrm{E}+01$ \\
\hline 50 & 19.89 & $1.28 \mathrm{E}-04$ & Laminar & $1.76 \mathrm{E}-03$ & $1.42 \mathrm{E}+02$ & $7.10 \mathrm{E}+01$ \\
\hline
\end{tabular}

As indicated in Table 4, the minimum necessary crack Tength to exceed offsite guidelines corresponds to a solution concentration of $10 \%$, with a minimum crack length of $1.02 \mathrm{~m}(40 \mathrm{in.})$. Therefore, in order for the offsite guideline to be exceeded, an optimum crack length of at least $1.02 \mathrm{~m}$ (40 in.) must be formed.

To determine if offsite consequences can be reached it is necessary to determine if the cargo tank will support a $1.02 \mathrm{~m}$ (40 in.) crack before rupturing. During a cargo tank rupture event the crack would split wide open, no longer supporting the fine spray necessary to aerosolize the sodium hydroxide. The worst case crack length for a spray is therefore directly prior to cargo tank rupture, assuming the crack is maintained at an optimum width to produce a fine spray.

The length at which a crack in a given material will propagate suddenly towards cargo tank rupture can be determined using fracture mechanics. When the stress intensity of the crack exceeds the fracture toughness of the given material, the crack will propagate rapidly. The cargo tank parameters can be used to calculate the stress intensity, as well as the maximum crack length reached before the fracture toughness is exceeded. 
Typically, sodium hydroxide cargo tanks are constructed of 316 stainless steel. Stainless steel 316 is extremely ductile and no fracture toughness value exists. A crack is not likely to propagate suddenly towards rupture. It is more likely that the crack will continue to grow in length until the pressure within the cargo tank is relieved. Since the critical crack length is not ascertainable it is necessary to assume the crack length can exceed that necessary to achieve offsite consequences $[1.02 \mathrm{~m}(40 \mathrm{in})$.$] .$

\subsection{Sudden Failure of Cargo Tank}

A detailed source term and consequence model is not developed for sudden cargo tank failure. Instead, a screening calculation, designed to simplify the analysis, is performed to provide the basis for determining if the onsite or offsite evaluation guidelines are challenged.

The basis of the screening calculation is the estimation of the quantity of sodium hydroxide solution which must be made airborne in order to exceed onsite or offsite evaluation guidelines.

The onsite evaluation guideline for sodium hydroxide is $2 \mathrm{mg} / \mathrm{m}^{3}$ for the anticipated frequency category (Van Keuren 1996). Since the sudden cargo tank failure release occurs in a very short period of time it can be modeled as a puff release. The puff release $x / Q$ value for the onsite receptor is $9.85 \times 10^{-3} / \mathrm{m}^{3}$ (Van Keuren 1996). Thus, the source term of sodium hydroxide which would exceed the onsite guideline is:

$$
\begin{aligned}
\text { Onsite Source Term } & =\left(2 \mathrm{mg} / \mathrm{m}^{3}\right) /\left(9.85 \times 10^{-3} / \mathrm{m}^{3}\right) \\
& =203 \mathrm{mg} .
\end{aligned}
$$

The sodium hydroxide is in a solution with a maximum concentration of $50 \mathrm{wt} \%$. Therefore, assuming a $50 \mathrm{wt} \%$ solution, twice as much solution (as opposed to pure sodium hydroxide) must be transported downwind for a total source term of $406 \mathrm{mg}$, or $0.406 \mathrm{~g}$ of sodium hydroxide solution.

The density of a 50 wt\% sodium hydroxide solution is approximately $1.5 \mathrm{~g} / \mathrm{mL}$. The source term of $0.406 \mathrm{~g}$ is then $0.271 \mathrm{~mL}$, or $7.2 \times 10^{-5} \mathrm{gal}$.

Given the failure mechanism and associated forces associated with sudden cargo tank failure, it is obvious that a $0.4 \mathrm{~g}$ source term is feasible. Therefore, it is concluded that the onsite evaluation guideline would be exceeded by the consequences of this event and no further analys is is performed.

The offsite evaluation guideline for sodium hydroxide is $2 \mathrm{mg} / \mathrm{m}^{3}$ for the anticipated frequency category (Van Keuren 1996). The puff release $X / Q$ value for the offsite receptor is $1.14 \times 10^{-7} / \mathrm{m}^{3}$ (Van Keuren 1996). Thus, the source term of sodium hydroxide which would result in exceeding of the offsite guideline is:

$$
\begin{aligned}
\text { Offsite Source Term } & =\left(2 \mathrm{mg} / \mathrm{m}^{3}\right) /\left(1.14 \times 10^{-7} / \mathrm{m}^{3}\right) \\
& =1.75 \times 10^{7} \mathrm{mg} .
\end{aligned}
$$


Twice as much solution (as opposed to pure sodium hydroxide) must be transported downwind for a total source term of $3.51 \times 10^{7} \mathrm{mg}$, or $3.51 \times 10^{4} \mathrm{~g}$ of sodium hydroxide solution.

Using the density of $1.5 \mathrm{~g} / \mathrm{mL}$, the source term of $3.51 \times 10^{4} \mathrm{~g}$ is $2.34 \times 10^{4} \mathrm{~mL}$, or $23 \mathrm{~L}$. Thus, if $23 \mathrm{~L}(6.2$ gal $)$ of solution were made airborne and transported downwind, the offsite evaluation guidel ine would be exceeded. Unlike the calculation for the onsite receptor, it is not readily obvious if a $23 \mathrm{~L}$ (6.2 gal) source term from the cargo tank is possible. A more detailed analysis of the offsite source term and consequence is necessary.

The source term of $23 \mathrm{~L}(6.2$ gal) represents a release fraction of $8.9 \times 10^{-4}$, assuming a ful1 26,500-L (7,000-gal) cargo tank of the sodium hydroxide solution. DOE-HDBK-3010-94 indicates in Section 3.2.2.3.2 that overall containment failure (sudden tank failure) can have release fractions from $5 \times 10^{-5}$ for all low pressure (less than $345 \mathrm{kPa}$ or $50 \mathrm{psig}$ ) solutions, to $2 \times 10^{-3}$ for high pressure (greater than $345 \mathrm{kPa}$ or $50 \mathrm{psig}$ ), low density (< $1.2 \mathrm{~g} / \mathrm{cm}^{3}$ ) solutions or $1 \times 10^{-3}$ for high pressure, high density solutions. The maximum allowable pressure inside the cargo tank is $863 \mathrm{kPa}$ (125 psig) and the density of the solution is $1.5 \mathrm{~g} / \mathrm{cm}^{3}$. Therefore, the proper release fraction for the sudden cargo tank failure would be $1 \times 10^{-3}$ for the high density, high pressure release. These release fractions do not consider reduction of the source term based on the respirable fractions from DOE-HDBK-3010-94, because sodium hydroxide attacks the eyes, nose, and mouth, and will not be readily ejected from the lungs once larger particles are inhaled.

The actual release fraction of $1 \times 10^{-3}$ is greater than the release fraction required to exceed the offsite guideline $\left(8.9 \times 10^{-4}\right)$. Therefore, the actual release would be greater than that required to exceed the offsite guideline. Based on the release fractions, it can be concluded that the offsite guideline could be exceeded by the consequences of the sudden cargo tank failure. 


\subsection{RESULTS}

\subsection{Spray from Skid System Failure}

By the definition of the $x / Q$, the maximum air concentration of $\mathrm{NaOH}$ at a receptor location is just the product of the maximum release rate and the receptor $x / Q$. The resulting onsite and site boundary air concentrations of small particle $\mathrm{NaOH}$ is shown in Table 7 .

Table 7: Resulting $\mathrm{NaOH}$ air concentrations

\begin{tabular}{|c|c|c|c|}
\hline \multirow{2}{*}{$\% \mathrm{NaOH}$} & \multirow{2}{*}{$\begin{array}{c}\text { Respirable } \\
\text { Rate }(\mathrm{mg} / \mathrm{s})\end{array}$} & \multicolumn{2}{|c|}{ Release Concentration $\left(\mathrm{mg} / \mathrm{m}^{3}\right)$} \\
\cline { 3 - 4 } & $1.93 \mathrm{E}+02$ & $6.58 \mathrm{E}+00$ & Site Boundary \\
\hline 5 & $2.04 \mathrm{E}+02$ & $6.96 \mathrm{E}+00$ & $5.46 \mathrm{E}-03$ \\
\hline 10 & $1.68 \mathrm{E}+03$ & $5.73 \mathrm{E}+01$ & $5.77 \mathrm{E}-03$ \\
\hline 12 & $1.53 \mathrm{E}+03$ & $5.22 \mathrm{E}+01$ & $4.75 \mathrm{E}-02$ \\
\hline 15 & $1.07 \mathrm{E}+03$ & $3.65 \mathrm{E}+01$ & $4.33 \mathrm{E}-02$ \\
\hline 20 & $3.84 \mathrm{E}+02$ & $1.31 \mathrm{E}+01$ & $3.03 \mathrm{E}-02$ \\
\hline 30 & $1.66 \mathrm{E}+02$ & $5.66 \mathrm{E}+00$ & $1.09 \mathrm{E}-02$ \\
\hline 40 & $8.40 \mathrm{E}+01$ & $2.86 \mathrm{E}+00$ & $4.70 \mathrm{E}-03$ \\
\hline 50 & & & $2.38 \mathrm{E}-03$ \\
\hline
\end{tabular}

These results are considered very conservative in this case since they do not take credit for the initially rapid fallout rate of the large liquid particles prior to evaporation of the liquid fraction.

\subsection{Spray Leak from Crack in Cargo Tank}

The resulting onsite and site boundary air concentrations of small particle $\mathrm{NaOH}$ are shown in Table 8.

Table 8. Resulting Spray Leak NaOH Air Concentrations.

\begin{tabular}{|c|c|c|c|}
\hline & \multirow{2}{*}{$\begin{array}{c}\text { Minimum } \\
\text { Necessary } \\
\text { Crack Length }\end{array}$} & Onsite $(100 \mathrm{~m})$ & Site Boundary \\
\cline { 3 - 4 } & $(\mathrm{m})$ & Concentration $\left(\mathrm{mg} / \mathrm{m}^{3}\right)$ \\
\hline 10 & 1.02 & Above Guidel ines \\
\hline
\end{tabular}




\subsection{Sudden Failure of Cargo Tank}

The resulting onsite and site boundary air concentrations of small particle $\mathrm{NaOH}$ are shown in Table 9 for the sudden cargo tank failure.

Table 9. Resulting Sudden Cargo Tank Failure $\mathrm{NaOH}$ Air Concentrations.

\begin{tabular}{|c|c|c|}
\hline \multirow{2}{*}{$\% \mathrm{NaOH}$} & \multicolumn{2}{|c|}{ Concentration $\left(\mathrm{mg} / \mathrm{m}^{3}\right)$} \\
\cline { 2 - 3 } & Onsite $(100 \mathrm{~m})$ & Site Boundary \\
\hline 50 & \multicolumn{2}{|c|}{ Above Guidel ines } \\
\hline
\end{tabular}




\subsection{CONCLUSION}

The caustic spray leak analyzed here has been assigned a frequency of occurrence in the anticipated range $\left(10^{-2}-10^{+0} / \mathrm{y}\right)$. The risk guidelines for onsite and site boundary receptors for this frequency range are ERPG-I and PEL-TWA. Both criteria are $2 \mathrm{mg} / \mathrm{m}^{3}$ for $\mathrm{NaOH}$ (Van Keuren 1995). The concentrations at the receptor points and the resulting sum-of-fractions of the risk guidelines are shown in Table 6 .

Table 6: Receptor exposures to $\mathrm{NaOH}$

\begin{tabular}{|c|c|c|}
\hline Receptor & $\begin{array}{c}\mathrm{NaOH} \\
\begin{array}{c}\text { Concentration } \\
(\mathrm{mg} / \mathrm{m} 3)\end{array} \\
\end{array}$ & $\begin{array}{l}\text { Sum-of- } \\
\text { Fractions }\end{array}$ \\
\hline \multicolumn{3}{|c|}{ Spray Leak from Skid System Failure } \\
\hline Onsite $(100 \mathrm{~m} \mathrm{E})$ & $5.73 E+01$ & 29 \\
\hline Site Boundary $(8.76 \mathrm{~km} \mathrm{~N})$ & $4.75 \mathrm{E}-02$ & 0.024 \\
\hline \multicolumn{3}{|c|}{ Spray Leak from Crack in Cargo Tank } \\
\hline Onsite $(100 \mathrm{~m} \mathrm{E})$ & $\begin{array}{c}\text { Above } \\
\text { Guidelines }\end{array}$ & $>1$ \\
\hline Site Boundary $(8.76 \mathrm{~km} \mathrm{~N})$ & $\begin{array}{c}\text { Above } \\
\text { Guidelines }\end{array}$ & $>1$ \\
\hline \multicolumn{3}{|c|}{ Sudden Failure of Cargo Tank } \\
\hline Onsite $(100 \mathrm{~m} \mathrm{E})$ & $\begin{array}{c}\text { Above } \\
\text { Guidelines }\end{array}$ & $>1$ \\
\hline Site Boundary $(8.76 \mathrm{~km} \mathrm{~N})$ & $\begin{array}{c}\text { Above } \\
\text { Guidelines }\end{array}$ & $>1$ \\
\hline
\end{tabular}

For the spray leak from the skid system failure, the sum of fractions at the site boundary are far less than the toxicological risk criterion of 1 . The criterion is exceeded at the onsite receptor location.

Note that these results are for standard schedule 10 steel pipe. Use of a thinner wall pipe such as schedule 5 (wall thickness 0.065 in.) would increase the maximum release rate and receptor concentrations shown in Tables 5 and 6 by about 30\% (due to the smaller crack depth and decreased friction losses). There would be no changes in the conclusions.

For the spray leak from crack in cargo tank, the sum-of-fractions of risk guidelines is exceeded at both the offsite and onsite receptor locations.

For the sudden failure of the cargo tank, the sum-of-fractions of risk guidelines is exceeded at both the offsite and onsite receptor locations. 


\subsection{RECOMMENDATIONS FOR MITIGATION}

Since the liquid being transferred is relatively $\operatorname{cool}\left(<50{ }^{\circ} \mathrm{C}\right.$ ) and is at relatively low pressure ( $\leq 863 \mathrm{kPa}$ or $125 \mathrm{psig}$ ), containment of a possible spray release would be easy. Plastic sleeving or wrap taped in place around the fittings would be sufficient to contain the spray. Using the total optimal leak rate of $3.04 \times 10^{-5} \mathrm{~m}^{3} / \mathrm{s}$ (see attached Spray Code run for $12 \%$ solution) and the crack area produces a maximum liquid spray velocity of 26 $\mathrm{m} / \mathrm{s}$. Even assuming the spray to come out in a parallel (rather than a radial) stream, the maximum resulting reaction force of the worst-case spray would be about $0.88 \mathrm{~N}(0.20 \mathrm{lbf})$. Assuming the plastic to form a $90^{\circ}$ corner under the impact of the spray, the maximum stress produced in 4 mil material would be about $35 \mathrm{psi}$. Standard 4 mil polyethylene (or similar material) sleeving or wrap would therefore have ample strength to contain the spray. The sleeving/wrap would not be expected to be pressure tight, however, and the solution would still leak out, producing a minor local cleanup problem, but there would be no significant aerosol release.

The aerosol release rate for the mitigated spray can be estimated by calculating how much mist generated inside the plastic sleeving could be displaced out of the sleeving by the solution leaking out of the pipe. The maximum total solution leak rate equal to $7.18 \times 10^{-5} \mathrm{~m}^{3} / \mathrm{s}$ occurs at a solution concentration of $50 \%$ (see the GXQ results for $50 \%$ solution in attachment 1). This total leak rate is assumed to displace the same amount of air out of the sleeving. The maximum air loading of an aerosol mist is normally assumed to be $100 \mathrm{mg} / \mathrm{m}^{3}$ (ANSI N46.l 1980). However, since the air loading here is for a short-time transient condition, ten times this value, or $1 \mathrm{~g} / \mathrm{m}^{3}$ is assumed for conservatism. Then assuming that no liquid is leaking from the sleeving (it is just filling with liquid), a displaced volume rate of $7.18 \times 10^{-5} \mathrm{~m} / \mathrm{s}$ would force $7.18 \times 10^{-5} \mathrm{~g} / \mathrm{s}$ of solution, or $3.59 \times 10^{-2} \mathrm{mg} / \mathrm{s}$ of $\mathrm{NaOH}$, out of the sleeving. Using the same transport assumptions as before, the resulting receptor concentrations are $1.22 \times 10^{-3} \mathrm{mg} / \mathrm{m}^{3}$ and $1.02 \times 10^{-6} \mathrm{mg} / \mathrm{m}^{3}$ for the onsite and site boundary receptors, respectively. Both concentrations are negligible compared to the risk guidelines of $2 \mathrm{mg} / \mathrm{m}^{3}$ for both receptors. 


\subsection{REFERENCES}

ANSI N46.1, 1980, American National Standard - Guidance for Defining SafetyRelated Features of Nuclear Fuel Cycle Facilities, American Nuclear Society, La Grange Park, Illinois.

Chemetron 1969, Piping Engineering, Tube Turns Division of Chemetron Corporation, Louisville, Kentucky, October 1969.

DOE-HDBK-3010-YR, Airborne Release Fractions/Rates and Respirable Fractions for Nonreactor Nuclear Facilities, U.S. Department of Energy, Washington D.C., 1994.

Hey 1994, B.E. Hey, GXQ Program User's Guide, WHC-SD-GN-SWD-30002, Rev. 1, December 1994.

Hey and Leach 1994, B.E. Hey and D.S. Leach, A Model for Predicting Respirable Releases from Pressurized Leaks, WHC-SD-GN-SWD-20007 Rev 0, Apri1 1994.

Perry and Green 1984, R.H. Perry and D. Green, Perry's Chemical Engineers' Handbook, Sixth Edition, McGraw-Hi11, New York, 1984.

Van Keuren 1996, J.C. Van Keuren, Tank Waste Compositions and Atmospheric Dispersion Coefficients for use in Accelerated Safety Analysis Consequence Assessments, WHC-SD-WM-SARR-016 Rev 2, July 1996.

Van Keuren 1995, J.C. Keuren, J.S. Davis, and M.L. Dentler, Toxic Chemical Considerations for Tank Farm Releases, WHC-SD-WM-SARR-011 Rev 1, November 1995.

WHC 1996, Safety Assessment for Tank 241-C-106 Waste Retrieval Project W-320, WHC-SD-WM-SAD-024 Rev 0, May 1996. 
HNF-SD-WM-CN-065 Rev 2

Attachment 1 SPRAY Code Files 
SPRAY Version 3.0

May 3, 1994

Spray Leak Code

Produced by Radiological \& Toxicological Analysis Westinghouse Hanford Company

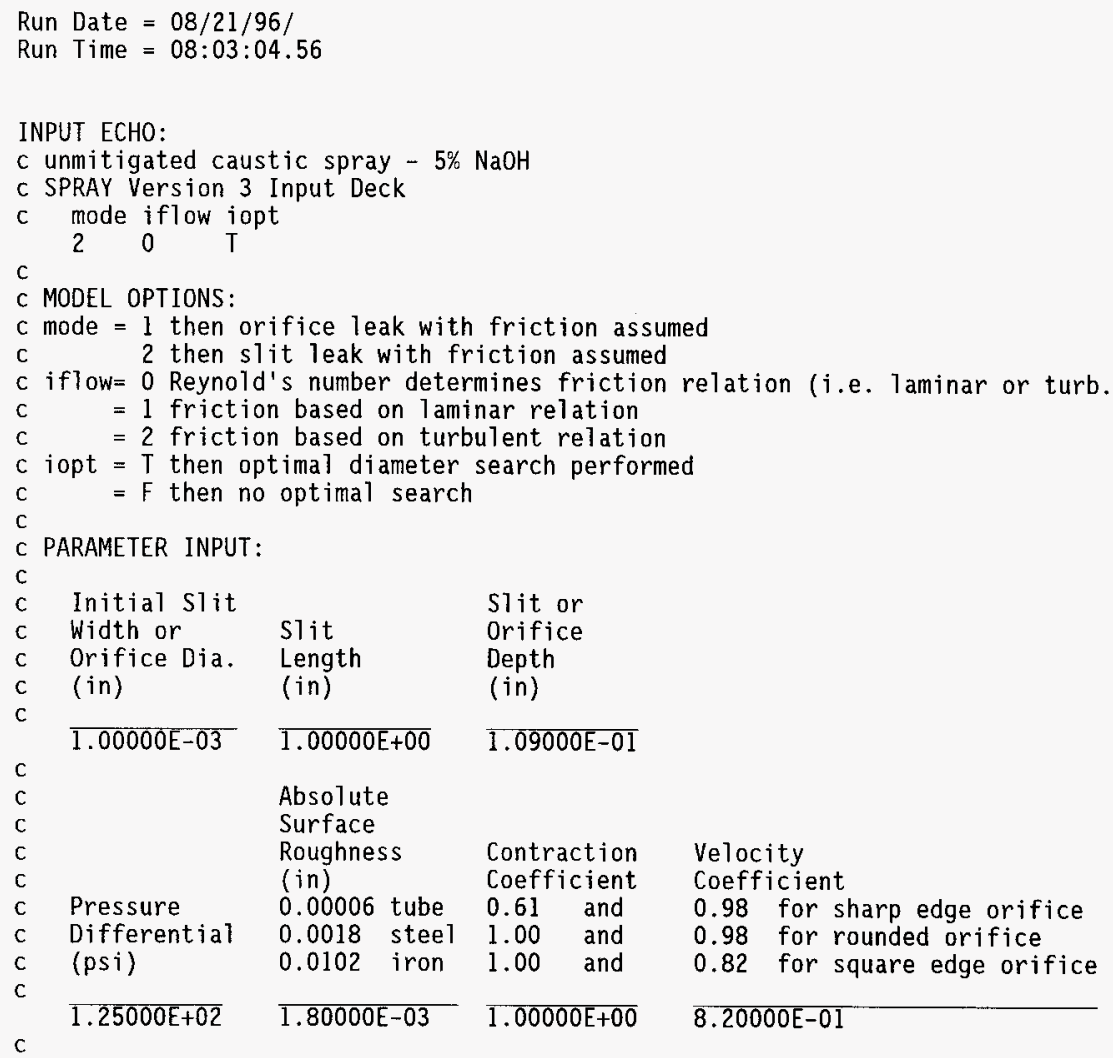




$\begin{array}{lllll}\text { c Fluid } & \begin{array}{l}\text { Dynamic } \\ \text { Ciscosity } \\ \text { (centi-poise) }\end{array} & \begin{array}{l}\text { Respirable } \\ \text { Diameter } \\ (\mu \mathrm{m})\end{array} & \begin{array}{l}\text { RR Fitting } \\ \text { Constant } \\ \text { c Gravity }\end{array} & \\ \text { C } & \overline{1.04100 E+00} & \overline{8.00000 E-01} & \overline{2.71000 E+01} & \overline{2.40000 E+00}\end{array}$

MESSAGES:

Sl it Model

Code search for optimal equivalent diameter.

OUTPUT :

Liquid Velocity $=6.76 \mathrm{E}+01 \mathrm{ft} / \mathrm{s} \quad 2.06 \mathrm{E}+01 \mathrm{~m} / \mathrm{s}$

Reynolds Number $=5.33 \mathrm{E}+03$ Turbulent Flow

Sauter Mean Diameter $=5.26 \mathrm{E}+01 \mu \mathrm{m}$

0ptimum Slit Width $=3.93 \mathrm{E}-03$ in

Respirable Fraction $=7.10 \mathrm{E}-02$

Tota 7 Leak Rate $=8.28 \mathrm{E}-01 \mathrm{gpm}$

$9.99 \mathrm{E}-05 \mathrm{~m}$

Respirable Leak Rate $=5.88 \mathrm{E}-02 \mathrm{gpm}$

$5.22 \mathrm{E}-05 \mathrm{~m} 3 / \mathrm{s}$

$3.71 \mathrm{E}-06 \mathrm{~m} 3 / \mathrm{s}$

$5.44 \mathrm{E}+01 \mathrm{~g} / \mathrm{s}$

$3.86 \mathrm{E}+00 \mathrm{~g} / \mathrm{s}$ 
SPRAY Version 3.0

May 3, 1994

Spray Leak Code

Produced by Radiological \& Toxicological Analysis

Westinghouse Hanford Company

Run Date $=08 / 21 / 96 /$

Run Time $=08: 08: 31.64$

INPUT ECHO:

c unmitigated caustic spray - $10 \% \mathrm{NaOH}$

c SPRAY Version 3 Input Deck

c mode iflow iopt

$200 \quad T$

$\mathrm{C}$

c MODEL OPTIONS:

$c$ mode $=1$ then orifice leak with friction assumed

c 2 then slit leak with friction assumed

c iflow $=0$ Reynold's number determines friction relation (i.e. laminar or turb.

c $\quad=1$ friction based on laminar relation

c $\quad=2$ friction based on turbulent relation

c iopt $=T$ then optima 7 diameter search performed

c $=F$ then no optimal search

c

c PARAMETER INPUT:

$c$

c Initial S1it

c Width or Slit

c Orifice Dia. Length

c (in) (in)

c

C
$\overline{1.00000 E-03}$
$1.00000 \mathrm{E}+00$

Slit or

Orifice

Depth

(in)

c

Absolute

Surface

Roughness

(in)

Contraction

Coefficient

Pressure

0.00006 tube

0.61

and

Differential

0.0018 steel 1.00

and

0.0102 iron 1.00 and

Velocity

Coefficient

(psi)

$1.80000 \mathrm{E}-03$

$\overline{1.00000 E+00}$

0.98 for sharp edge orifice

0.98 for rounded orifice

0.82 for square edge orifice

c

$\overline{1.25000 E+02}$

$1.8000 \mathrm{E}-03$

\section{$8.20000 \mathrm{E}-01$}




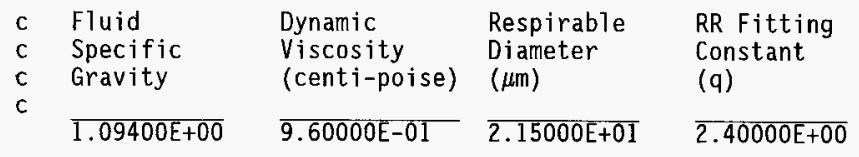

MESSAGES :

Sl it Mode?

Code search for optimal equivalent diameter.

OUTPUT:

Liquid Velocity $=6.53 \mathrm{E}+01 \mathrm{ft} / \mathrm{s} \quad 1.99 \mathrm{E}+01 \mathrm{~m} / \mathrm{s}$

Reynolds Number $=4.43 \mathrm{E}+03$ Turbulent Flow

Sauter Mean Diameter $=5.48 \mathrm{E}+01 \mu \mathrm{m}$

Optimum Slit Width $=3.86 \mathrm{E}-03$ in

Respirable Fraction $=3.76 \mathrm{E}-02$

$\begin{aligned} \text { Total Leak Rate } & =7.86 \mathrm{E}-01 \mathrm{gpm} \\ \text { Respirable Leak Rate } & =2.96 \mathrm{E}-02 \mathrm{gpm}\end{aligned}$

9.81E-05 m

$4.96 \mathrm{E}-05 \mathrm{~m} 3 / \mathrm{s}$

$1.87 \mathrm{E}-06 \mathrm{~m} 3 / \mathrm{s}$

$5.42 \mathrm{E}+01 \mathrm{~g} / \mathrm{s}$

$2.04 \mathrm{E}+00 \mathrm{~g} / \mathrm{s}$ 
SPRAY Version 3.0

May 3, 1994

Spray Leak Code

Produced by Radiological \& Toxicological Analysis

Westinghouse Hanford Company

Run Date $=08 / 21 / 96 /$

Run Time $=08: 24: 57.06$

INPUT ECHO:

c unmitigated caustic spray - $12 \% \mathrm{NaOH}$

c SPRAY Version 3 Input Deck

c mode iflow iopt

C $2 \quad 1 \quad$ T

c MODEL OPTIONS:

c mode $=1$ then orifice leak with friction assumed

c 2 then slit leak with friction assumed

$c$ iflow $=0$ Reynold's number determines friction relation (i.e. laminar or turb.

c $=1$ friction based on laminar relation

c $\quad=2$ friction based on turbulent relation

c iopt $=\mathrm{T}$ then optimal diameter search performed

$c=F$ then no optimal search

$\mathrm{C}$

c PARAMETER INPUT:

c

c Initial S1it

c Width or

c Orifice Dia.

c (in)

Slit or

C
$1.00000 \mathrm{E}-03$
$1.00000 \mathrm{E}+00 \quad 1.09000 \mathrm{E}-01$

Slit

Length

Orifice

(in)

Depth

(in)

c

c

c

c

C

C

C

C

c

c

\section{Absolute}

Surface

Roughness

(in)

Pressure

0.00006 tube

Contraction

Coefficient

VeTocity

Differential

0.0018 steel

0.61

and

Coefficient

(psi)

0.0102 iron 1.00

and

0.98 for sharp edge orifice

0.98 for rounded orifice

$1.25000 E+02$

$\overline{1.80000 E-03}$

$\overline{1.00000 E+00}$

0.82 for square edge orifice

c

$1.25000 \mathrm{E}+02$ 1.80000 03 . $1.0000 \mathrm{E}+00$

$8.20000 \mathrm{E}-01$ 


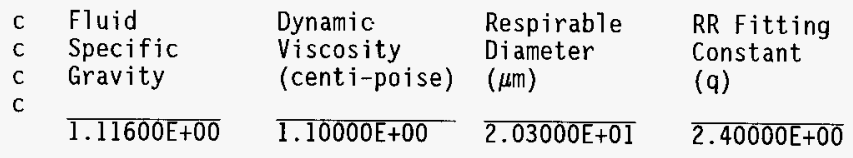

MESSAGES:

Slit Model

Code search for optimal equivalent diameter.

Friction factor based on laminar flow.

OUTPUT:

Liquid Velocity $=8.54 \mathrm{E}+01 \mathrm{ft} / \mathrm{s} \quad 2.60 \mathrm{E}+01 \mathrm{~m} / \mathrm{s}$

Reynolds Number $=2.43 \mathrm{E}+03$ Critical Flow

Sauter Mean Diameter $=1.73 \mathrm{E}+01 \mu \mathrm{m}$

Optimum S1it Width $=1.81 \mathrm{E}-03$ in

Respirable Fraction $=4.12 \mathrm{E}-01$

Total Leak Rate $=4.82 \mathrm{E}-01 \mathrm{gpm} \quad 3.04 \mathrm{E}-05 \mathrm{~m} 3 / \mathrm{s} \quad 3.40 \mathrm{E}+01 \mathrm{~g} / \mathrm{s}$

Respirable Leak Rate $=1.98 \mathrm{E}-01 \mathrm{gpm} \quad 1.25 \mathrm{E}-05 \mathrm{~m} 3 / \mathrm{s} \quad 1.40 \mathrm{E}+01 \mathrm{~g} / \mathrm{s}$ 
SPRAY Version 3.0

May 3, 1994

Spray Leak Code

Produced by Radiological \& Toxicological Analysis

Westinghouse Hanford Company

$$
\text { Run Date }=08 / 21 / 96 /
$$

Run Time $=08: 28: 44.89$

INPUT ECHO:

C unmitigated caustic spray - $15 \% \mathrm{NaOH}$

c SPRAY Version 3 Input Deck

c mode iflow iopt

$\mathrm{C}$ $\begin{array}{llll}2 & 1 & T\end{array}$

C MODEL OPTIONS:

$c$ mode $=1$ then orifice leak with friction assumed

c 2 then slit leak with friction assumed

$c$ iflow $=0$ Reynold's number determines friction relation (i.e. laminar or turb.

c $=1$ friction based on laminar relation

c $=2$ friction based on turbulent relation

c iopt $=T$ then optimal diameter search performed

$c \quad=F$ then no optimal search

C

c PARAMETER INPUT:

C

c Initial slit

c Width or S1it

c Orifice Dia.

c (in)

Length

(in)

Slit or

C

$\overline{1.00000 E-03} \overline{1.00000 E+00} \quad \overline{1.09000 E-01}$

C

$\mathrm{C}$

Absolute

Surface

C

Pressure Roughness

Differential

(in)

Orifice

Depth

(in)

(psi)

0.00006 tube

Contraction

Coefficient Coefficient

Velocity

c

$\overline{1.25000 \mathrm{E}+02} \overline{1.80000 \mathrm{E}-03} \overline{1.00000 \mathrm{E}+00}$

0.0018 steel 1.00

and

0.98 for sharp edge orifice

0.0102 iron 1.00

and

0.98 for rounded orifice

0.82 for square edge orifice

$8.20000 \mathrm{E}-01$ 


\begin{tabular}{|c|c|c|c|c|}
\hline$c$ & Fluid & Dynamic & Respirable & RR Fitting \\
\hline & Specific & Viscosity & Diameter & Constant \\
\hline & Gravity & (centi-poise) & $(\mu \mathrm{m})$ & (q) \\
\hline & $1.14800 \mathrm{E}+00$ & $1.30000 \mathrm{E}+00$ & $\overline{1.88000 \mathrm{E}+01}$ & $2.40000 \mathrm{E}+$ \\
\hline
\end{tabular}

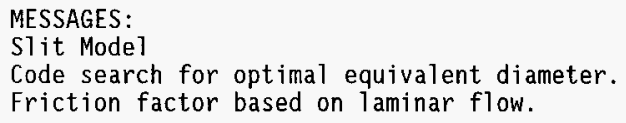


HNF-SD-WM-CN-065 Rev 2

SPRAY Version 3.0

May 3, 1994

Spray Leak Code

Produced by Radiological \& Toxicological Analysis

Westinghouse Hanford Company

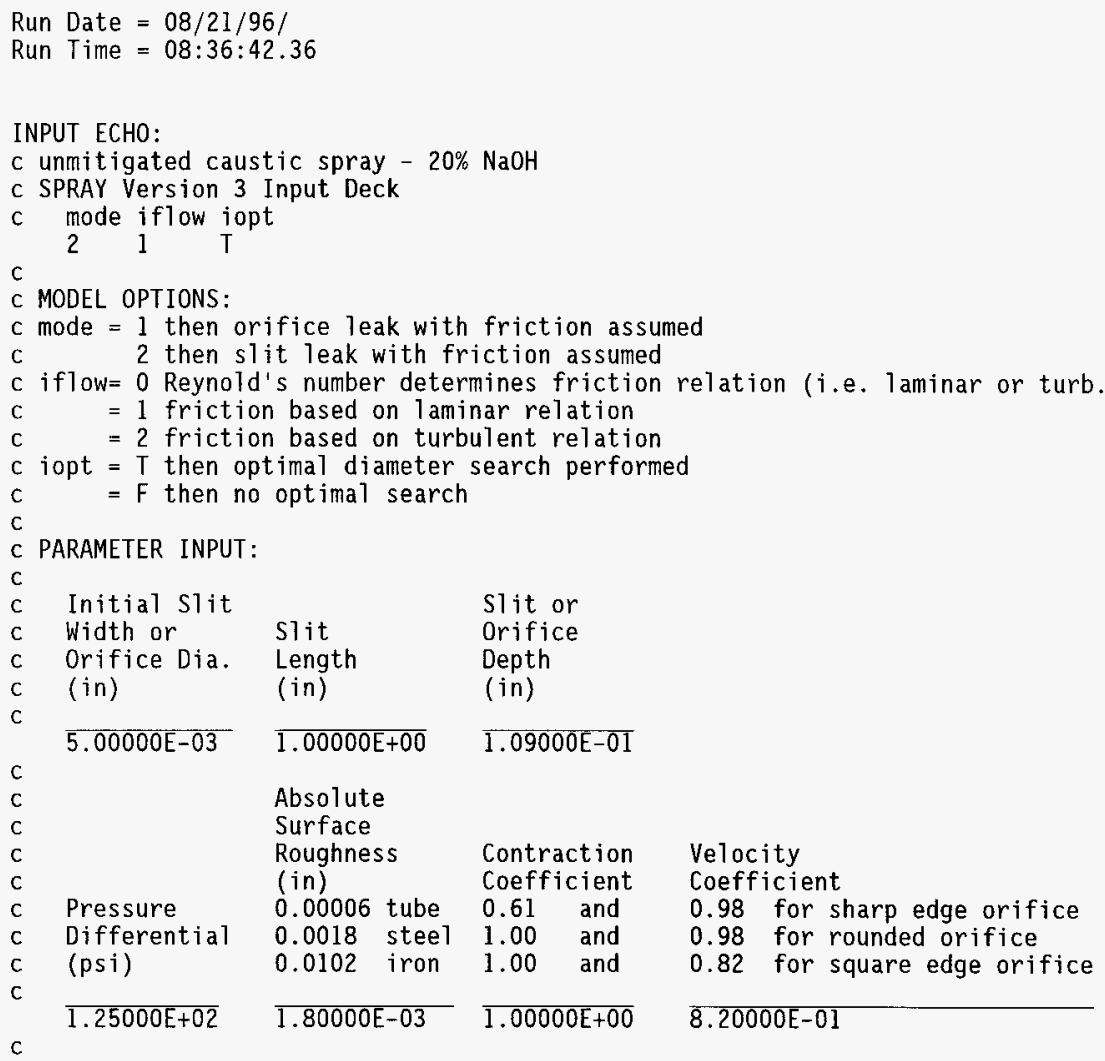




$\begin{array}{lllll}\text { c Fluid } & \begin{array}{l}\text { Dynamic } \\ \text { C Specific }\end{array} & \begin{array}{l}\text { Respirable } \\ \text { Discosity } \\ \text { (centi-poise) }\end{array} & \begin{array}{l}\text { RR Fitting } \\ (\mu \mathrm{m})\end{array} & \begin{array}{l}\text { Constant } \\ (\mathrm{q})\end{array} \\ \text { c Gravity } & & & \\ \text { c } & \overline{1.20200 \mathrm{E}+00} & \overline{1.90000 \mathrm{E}+00} & \overline{1.71000 \mathrm{E}+01} & \overline{2.40000 \mathrm{E}+00}\end{array}$

MESSAGES:

Slit Model

Code search for optimal equivalent diameter.

Friction factor based on laminar flow.

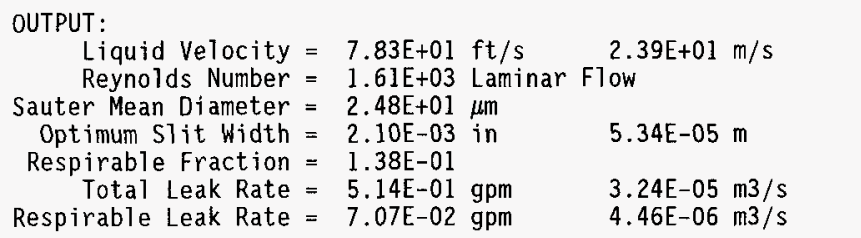


SPRAY Version 3.0

May 3, 1994

Spray Leak Code

Produced by Radiological \& Toxicological Analysis

Westinghouse Hanford Company

Run Date $=08 / 21 / 96 /$

Run Time $=08: 39: 43.06$

INPUT ECHO:

c unmitigated caustic spray - $30 \% \mathrm{NaOH}$

c SPRAY Version 3 Input Deck

c mode iflow iopt

$200 \quad \mathrm{~T}$

$\mathrm{C}$

c MODEL OPTIONS:

c mode $=1$ then orifice leak with friction assumed

c 2 then slit leak with friction assumed

c iflow $=0$ Reynold's number determines friction relation (i.e. laminar or turb.

c $=1$ friction based on laminar relation

c $\quad=2$ friction based on turbulent relation

c jopt $=T$ then optimal diameter search performed

$\mathrm{c}=\mathrm{F}$ then no optimal search

$\mathrm{C}$

c PARAMETER INPUT:

$\mathrm{C}$

c Initial S1it

c Width or

c Orifice Dia.

c (in)

C
$\overline{5.00000 E-0} \overline{3}$

\section{$\overline{1.00000 \mathrm{E}+00} \quad \overline{1.09000 \mathrm{E}-01}$}

Slit

Slit or

Length

Orifice

(in)

Depth

(in)

c

c

c

C

C

$\mathrm{C}$

c

c

c

Absolute

Surface

Roughness

Contraction

Coefficient

Velocity

(in)

0.61 and

Coefficient

Pressure

0.00006 tube

0.0018 steel 1.00

and

0.98 for sharp edge orifice

Differential

0.0102 iron 1.00 and

0.98 for rounded orifice

0.82 for square edge orifice

\section{$\overline{1.25000 E+02}$}

$\overline{1.80000 E-03}$

$\overline{1.00000 E+00}$

$8.20000 \mathrm{E}-01$ 


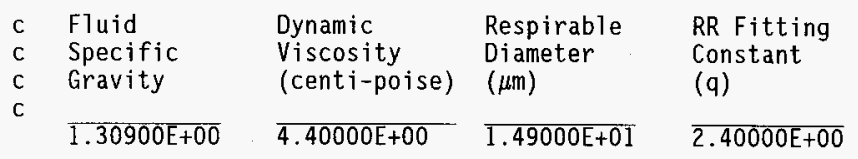

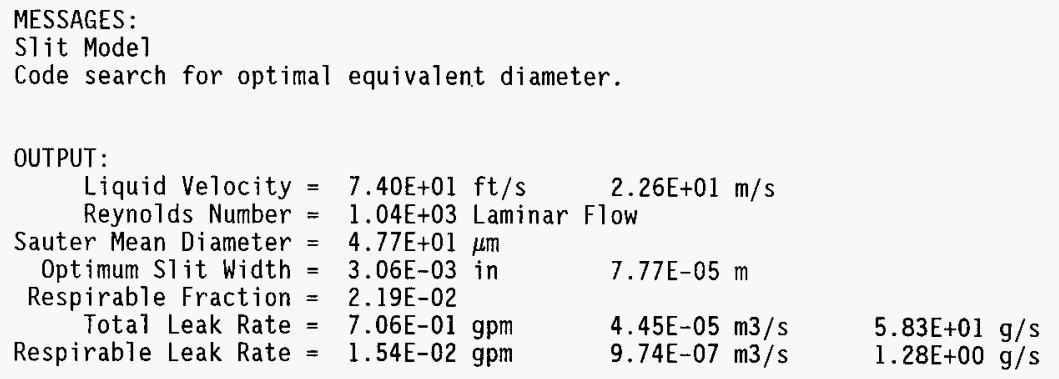


SPRAY Version 3.0

May 3, 1994

Spray Leak Code

Produced by Radiological \& Toxicological Analysis

Westinghouse Hanford Company

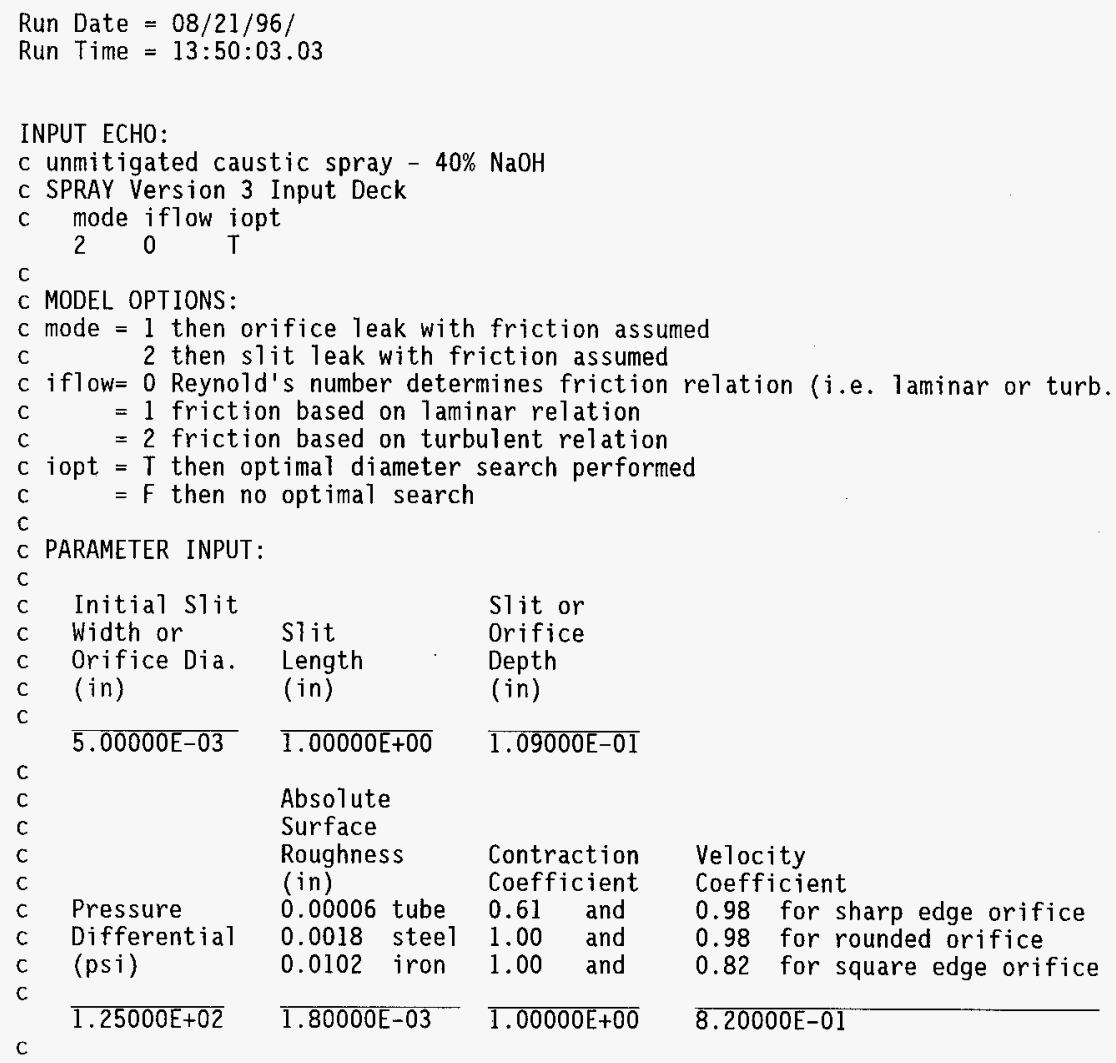




$\begin{array}{lllll}\text { c Fluid } & \text { Dynamic } & \text { Respirable } & \text { RR Fitting } \\ \text { c } & \text { Specific } & \begin{array}{l}\text { Viscosity } \\ \text { (centi-poise) }\end{array} & \begin{array}{l}\text { Diameter } \\ (\mu \mathrm{m})\end{array} & \begin{array}{l}\text { Constant } \\ \text { c }\end{array} \\ \text { C } & & & & \\ & \overline{1.41000 \mathrm{E}+00} & \overline{8.50000 \mathrm{E}+00} & \overline{1.36000 \mathrm{E}+01} & \overline{2.40000 \mathrm{E}+00}\end{array}$

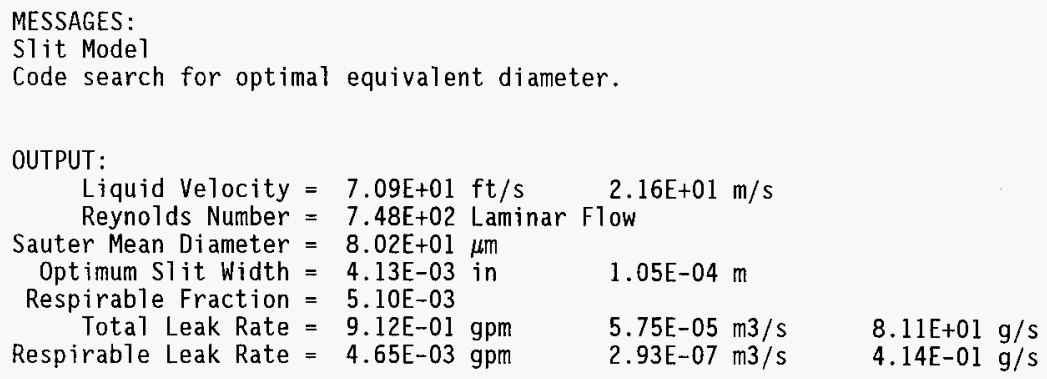


SPRAY Version 3.0

May 3, 1994

Spray Leak Code

Produced by Radiological \& Toxicological Analysis

Westinghouse Hanford Company

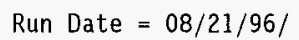

Run Date $=08 / 21 / 96 /$

Run Time $=13: 52: 17.92$

\section{INPUT ECHO :}

c unmitigated caustic spray - $50 \% \mathrm{NaOH}$

c SPRAY Version 3 Input Deck

c mode iflow iopt $200 \quad T$

$\mathrm{C}$

c MODEL OPTIONS:

$c$ mode $=1$ then orifice leak with friction assumed

c 2 then slit leak with friction assumed

c iflow $=0$ Reynold's number determines friction relation (i.e. laminar or turb.

c $=1$ friction based on laminar relation

c $=2$ friction based on turbulent relation

$c$ iopt $=\mathrm{T}$ then optimal diameter search performed

$c=F$ then no optimal search

$\mathrm{C}$

C PARAMETER INPUT:

$\mathrm{C}$

c Initial slit

c Width or

c Orifice Dia.

c (in)

c
$5.00000 \mathrm{E}-03$

\section{$\overline{1.00000 \mathrm{E}+00 \quad \overline{1.09000 \mathrm{E}-01}}$}

Slit

Length

Slit or

(in) (in)

Orifice

Depth

(in)

C

c

c

$\mathrm{c}$

c

c

$\mathrm{c}$

C

Absolute

Surface

Roughness

Contraction

Coefficient

Velocity

(in)

0.61 and

Coefficient

Pressure

0.00006 tube

1.00

and

0.98 for sharp edge orifice

Differential

0.0018

steel

0.0102 iron 1.00

and

0.98 for rounded orifice

(psi)

0.82 for square edge orifice

\section{$\overline{1.25000 E+02}$}

$\overline{1.80000 \mathrm{E}-03}$

$\overline{1.00000 \mathrm{E}+00}$

8.20000E-01 


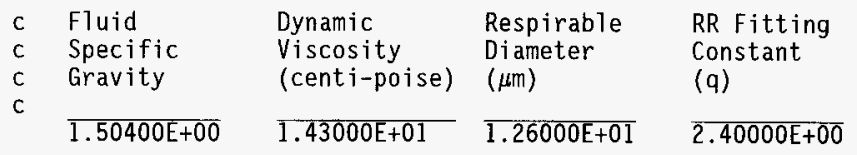

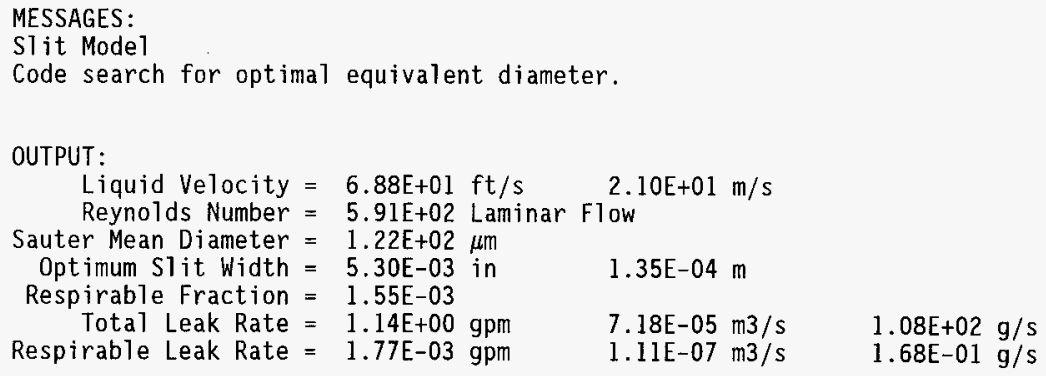


SPRAY Version 3.0

May 3

Spray Leak Code

Produced by Radiological \& Toxicological Analysis

Westinghouse Hanford Company

Run Date $=03 / 02 / 97 /$

Run Time $=13: 10: 19.21$

INPUT ECHO:

C SPRAY Version 3 Input Deck

c unmitigated caustic spray -

c mode iflow iopt

$\begin{array}{lll}2 & 1 & \mathrm{~T}\end{array}$

$\mathrm{C}$

c MODEL OPTIONS:

c mode $=1$ then orifice leak with friction assumed

c $\quad 2$ then slit leak with friction assumed

c iflow $=0$ Reynold's number determines friction relation (i.e. laminar or turb.

$\mathrm{c}=1$ friction based on laminar relation

c $\quad=2$ friction based on turbulent relation

c iopt $=\mathrm{T}$ then optimal diameter search performed

$c=F$ then no optimal search

C

c PARAMETER INPUT:

c Initial Slit

c Width or

c Orifice Dia.

c (in)

\section{$\overline{1.00000 E-03} \quad \overline{5.10000 E+01} \quad \overline{1.00000 E-01}$}

Absolute

Surface

Roughness

Contraction Coefficient

Velocity

(in)

Slit or

Orifice

Depth

(in)

Pressure

0.00006 tube

0.61 and

Coefficient

Differential

0.0018 stee? 1.00

and

0.98 for sharp edge orifice

(psi)

0.0102 iron 1.00

and

0.98 for rounded orifice

$\overline{1.25000 \mathrm{E}+02}$

$\overline{1.80000 \mathrm{E}-03}$

$\overline{1.00000 \mathrm{E}+00}$

0.82 for square edge orifice

C 


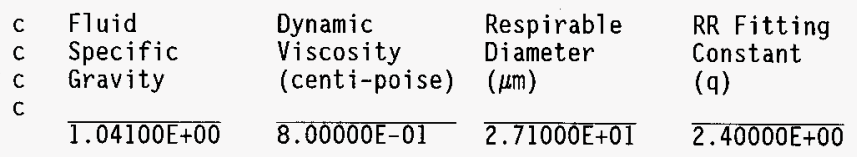

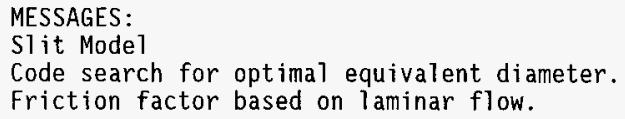


HNF-SD-WM-CN-065 Rev 2

SPRAY Version 3.0

May 3

Spray Leak Code

Produced by Radiological \& Toxicological Analysis

Westinghouse Hanford Company

Run Date $=03 / 02 / 97 /$

Run Time $=14: 56: 38.42$

INPUT ECHO:

c SPRAY Version 3 Input Deck

c unmitigated caustic spray - $8 \%$

c mode iflow iopt

$\begin{array}{lll}2 & 1 & \mathrm{~T}\end{array}$

C

c MODEL OPTIONS:

$c$ mode $=1$ then orifice leak with friction assumed

c $\quad 2$ then slit leak with friction assumed

c iflow $=0$ Reynold's number determines friction relation (i.e. laminar or turb.

$\mathrm{c} \quad=1$ friction based on laminar relation

c $\quad=2$ friction based on turbulent relation

c iopt $=T$ then optimal diameter search performed

$c \quad=F$ then no optimal search

C

c PARAMETER INPUT:

C

c Initial slit

c Width or

c Orifice Dia.

c (in)

$\overline{1.00000 \mathrm{E}-03}$

Length

Depth

(in)

(in)

C

C

c

C

c

$\mathrm{c}$

C

C

C

$\overline{4.20000 \mathrm{E}+01} \overline{1.00000 E-01}$

Absolute

Surface

Roughness

(in)

Contraction Velocity

Coefficient Coefficient

Pressure

0.00006 tube 0.61

and

0.98 for sharp edge orifice

Differential

0.0018 steel 1.00

and

0.98 for rounded orifice

(psi)

0.0102 iron 1.00

and

0.82 for square edge orifice

$\overline{1.25000 \mathrm{E}+02}$

$1.80000 \mathrm{E}-03$

$1.00000 E+00$

$8.20000 E-01$ 


\begin{tabular}{|c|c|c|c|}
\hline $\begin{array}{l}\text { Fluid } \\
\text { Specific } \\
\text { Gravity }\end{array}$ & $\begin{array}{l}\text { Dynamic } \\
\text { Viscosity } \\
\text { (centi-poise) }\end{array}$ & $\begin{array}{l}\text { Respirable } \\
\text { Diameter } \\
(\mu \mathrm{m})\end{array}$ & $\begin{array}{l}\text { RR Fitting } \\
\text { Constant } \\
\text { (q) }\end{array}$ \\
\hline$\overline{1.07300 E+00}$ & $8.90000 E-01$ & $\overline{2.32000 \mathrm{E}+0 \mathrm{I}}$ & $2.40000 E+00$ \\
\hline
\end{tabular}

MESSAGES:

Slit Mode]

Code search for optimal equivalent diameter.

Friction factor based on laminar flow.

$\begin{array}{rlrl}\text { OUTPUT: } & & & \\ \text { Liquid Velocity } & =9.22 \mathrm{E}+01 \mathrm{ft} / \mathrm{s} & 2.81 \mathrm{E}+01 \mathrm{~m} / \mathrm{s} & \\ \text { Reynolds Number } & =3.17 \mathrm{E}+03 \mathrm{Critical} \text { Flow } & & \\ \text { Sauter Mean Diameter } & =1.58 \mathrm{E}+01 \mathrm{\mu m} & & \\ \text { Optimum Slit Width } & =1.84 \mathrm{E}-03 \mathrm{in} & 4.68 \mathrm{E}-05 \mathrm{~m} & \\ \text { Respirable Fraction } & =5.96 \mathrm{E}-01 & & \\ \text { Total Leak Rate } & =2.22 \mathrm{E}+01 \mathrm{gpm} & 1.40 \mathrm{E}-03 \mathrm{~m} 3 / \mathrm{s} & 1.51 \mathrm{E}+03 \mathrm{~g} / \mathrm{s} \\ \text { Respirable Leak Rate } & =1.32 \mathrm{E}+01 \mathrm{gpm} & 8.36 \mathrm{E}-04 \mathrm{~m} 3 / \mathrm{s} & 8.97 \mathrm{E}+02 \mathrm{~g} / \mathrm{s}\end{array}$


SPRAY Version 3.0

May 3

Spray Leak Code

Produced by Radiological \& Toxicological Analysis Westinghouse Hanford Company

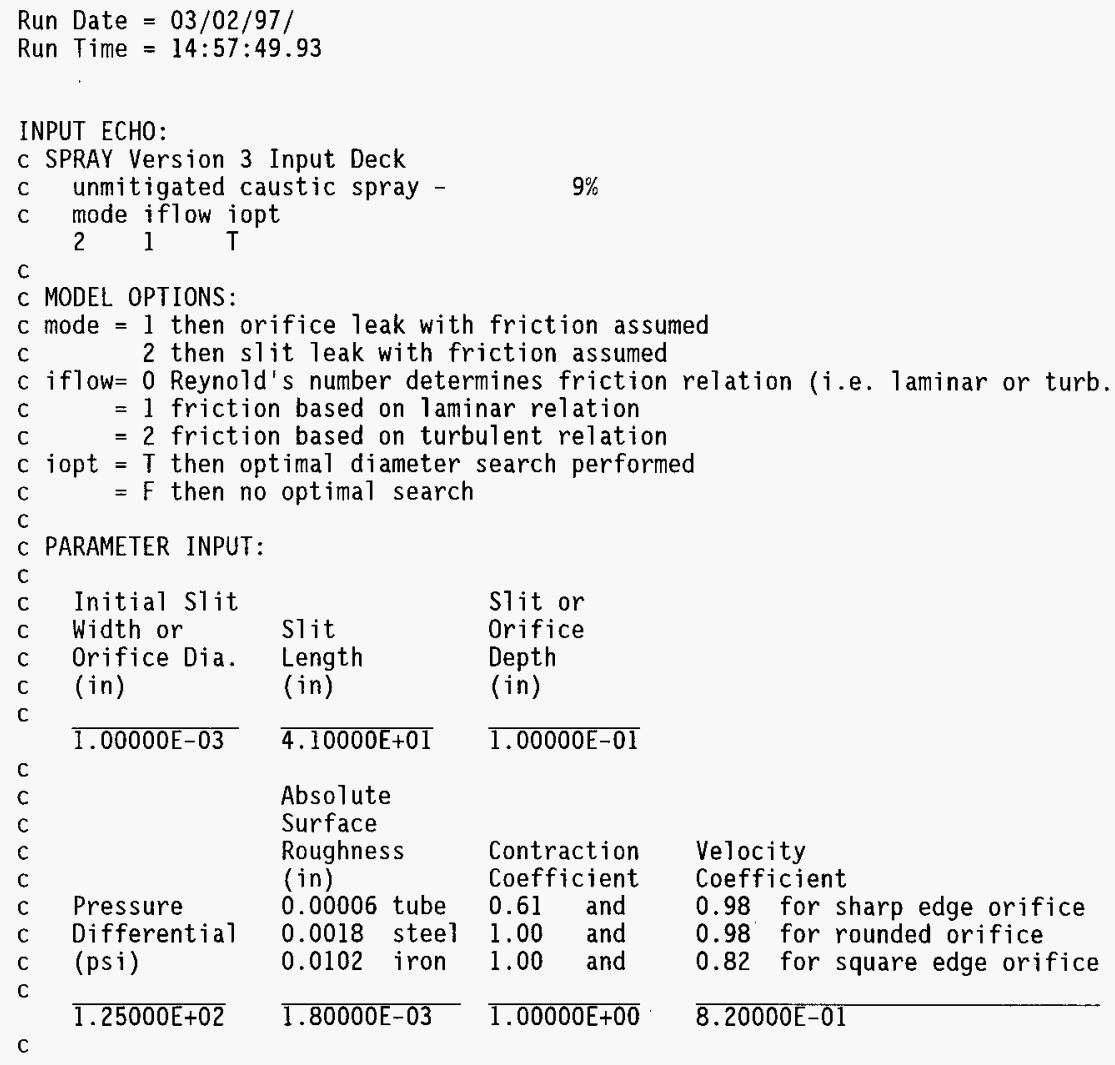




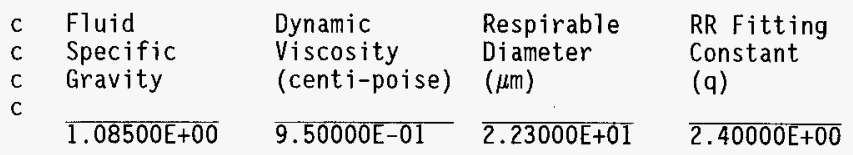

MESSAGES:

S1 it Model

Code search for optimal equivalent diameter.

Friction factor based on laminar flow.

OUTPUT:

Liquid Velocity $=9.03 \mathrm{E}+01 \mathrm{ft} / \mathrm{s} \quad 2.75 \mathrm{E}+01 \mathrm{~m} / \mathrm{s}$

Reynolds Number $=2.89 \mathrm{E}+03$ Critical Flow

Sauter Mean Diameter $=1.60 \mathrm{E}+01 \mu \mathrm{m}$

Optimum Slit Width $=1.81 \mathrm{E}-03$ in

Respirable Fraction $=5.52 \mathrm{E}-01$

Total Leak Rate $=2.09 \mathrm{E}+01 \mathrm{gpm}$

Respirable Leak Rate $=1.15 \mathrm{E}+01 \mathrm{gpm}$

4.59E-05 m

$1.32 \mathrm{E}-03 \mathrm{~m} 3 / \mathrm{s}$

$1.43 \mathrm{E}+03 \mathrm{~g} / \mathrm{s}$

$7.27 \mathrm{E}-04 \mathrm{~m} 3 / \mathrm{s}$

$7.89 \mathrm{E}+02 \mathrm{~g} / \mathrm{s}$ 
SPRAY Version 3.0

May 3

Spray Leak Code

Produced by Radiological \& Toxicological Analysis

Westinghouse Hanford Company

Run Date $=03 / 03 / 97 /$

Run Time $=07: 02: 45.08$

INPUT ECHO:

C SPRAY Version 3 Input Deck

c unmitigated caustic spray - $10 \%$

c mode iflow iopt

$2 \quad 1 \quad T$

$\mathrm{C}$

c MODEL OPTIONS:

$c$ mode $=1$ then orifice leak with friction assumed

c 2 then slit leak with friction assumed

$c$ iflow $=0$ Reynold's number determines friction relation (i.e. laminar or turb.

$\mathrm{c}=1$ friction based on laminar relation

$c=2$ friction based on turbulent relation

$c$ iopt $=\mathrm{T}$ then optimal diameter search performed

$\mathrm{c}=\mathrm{F}$ then no optimal search

$C$

C PARAMETER INPUT:

c Initial slit

c Width or

c Orifice Dia.

c (in)

$\mathrm{C}$

\section{$\overline{1.00000 E-03}$}

Slit

Length

(in)

$\overline{4.00000 E+01}$

Absolute

Surface

Roughness

(in)

Pressure

Differential

0.00006 tube

S1it or

Orifice

Depth

(in)

$1.00000 \mathrm{E}-01$

0.0018 steel

0.0102

1.00

Contraction

Coefficient

0.61 and

Velocity

Coefficient

0.98 for sharp edge orifice

(psi)

$\overline{1.25000 \mathrm{E}+02}$

$1.80000 \mathrm{E}-03$

$1.00000 \mathrm{E}+00$

0.98 for rounded orifice

0.82 for square edge orifice

c 


\begin{tabular}{|c|c|c|c|}
\hline $\begin{array}{l}\text { Fluid } \\
\text { Specific } \\
\text { Gravity }\end{array}$ & $\begin{array}{l}\text { Dynamic } \\
\text { Viscosity } \\
\text { (centi-poise) }\end{array}$ & $\begin{array}{l}\text { Respirable } \\
\text { Diameter } \\
(\mu \mathrm{m})\end{array}$ & $\begin{array}{l}\text { RR Fitting } \\
\text { Constant } \\
\text { (q) }\end{array}$ \\
\hline$\overline{1.09400 \mathrm{E}+00}$ & $\overline{9.60000 \mathrm{E}-01}$ & $\overline{2.15000 E+01}$ & $2.40000 E+00$ \\
\hline
\end{tabular}

\section{MESSAGES:}

S1 it Mode 1

Code search for optimal equivalent diameter.

Friction factor based on laminar flow.

OUTPUT:

Liquid Velocity $=8.90 \mathrm{E}+01 \mathrm{ft} / \mathrm{s}$

Reynolds Number $=2.77 \mathrm{E}+03$ Critical Flow

Sauter Mean Diameter $=1.57 \mathrm{E}+01 \mu \mathrm{m}$

Optimum S1it Width $=1.76 \mathrm{E}-03$ in

Respirable Fraction $=5.35 \mathrm{E}-01$

Total Leak Rate $=1.96 \mathrm{E}+01 \mathrm{gpm}$

Respirable Leak Rate $=1.05 \mathrm{E}+01 \mathrm{gpm}$
$4.48 \mathrm{E}-05 \mathrm{~m}$

1. $23 \mathrm{E}-03 \mathrm{~m} 3 / \mathrm{s}$

$6.60 \mathrm{E}-04 \mathrm{~m} 3 / \mathrm{s}$
1. $35 \mathrm{E}+03 \mathrm{~g} / \mathrm{s}$

$7.22 \mathrm{E}+02 \mathrm{~g} / \mathrm{s}$ 
HNF-SD-WM-CN-065 Rev 2

SPRAY Version 3.0

May 3

Spray Leak Code

Produced by Radiological \& Toxicological Analysis

Westinghouse Hanford Company

Run Date $=03 / 02 / 97 /$

Run Time $=15: 00: 45.03$

INPUT ECHO:

c SPRAY Version 3 Input Deck

c unmitigated caustic spray - $\quad 11 \%$

c mode iflow jopt

$\begin{array}{llll}2 & 1 & \mathrm{~T}\end{array}$

$\mathrm{C}$

C MODEL OPTIONS:

$c$ mode $=1$ then orifice leak with friction assumed

c 2 then slit leak with friction assumed

c iflow= 0 Reynold's number determines friction relation (i.e. laminar or turb.

$\mathrm{c}=1$ friction based on laminar relation

c $\quad=2$ friction based on turbulent relation

$c$ iopt $=T$ then optimal diameter search performed

$c=F$ then no optimal search

$\mathrm{C}$

c PARAMETER INPUT:

c Initial slit

c Width or Slit

c Orifice Dia.

c (in)

Length

Slit or

c

$$
\overline{1.00000 E-03}
$$

(in)

Orifice

Depth

(in)

C

c

c

c

C

c

c

Pressure

$4.30000 E+01$

$\overline{1.00000 E-01}$

Absolute

Surface

Roughness

Contraction Coefficient

Velocity

(in)

0.61 and

Coefficient

Differential

0.00006 tube 0.61

and

0.98 for sharp edge orifice

0.0018 steel 1.00

0.0102 iron 1.00 and

0.98 for rounded orifice

0.82 for square edge orifice

C

c

$1.80000 \mathrm{E}-03$

$1.00000 E+00$

8.20000E-01 


$\begin{array}{lllll}\text { c Fluid } & \begin{array}{l}\text { Dynamic } \\ \text { C Specific }\end{array} & \begin{array}{l}\text { Respirable } \\ \text { Viscosity } \\ \text { (centi-poise) }\end{array} & \begin{array}{l}\text { RR Fitting } \\ (\mu \mathrm{m})\end{array} & \begin{array}{l}\text { Constant } \\ (\mathrm{q})\end{array} \\ \text { c Gravity } & \overline{1.10000 \mathrm{E}+00} & \overline{2.08000 \mathrm{E}+01} & \overline{2.40000 \mathrm{E}+00}\end{array}$

MESSAGES :

Slit Model

Code search for optimal equivalent diameter.

Friction factor based on laminar flow.

OUTPUT :

Liquid Velocity $=8.64 \mathrm{E}+01 \mathrm{ft} / \mathrm{s} \quad 2.63 \mathrm{E}+01 \mathrm{~m} / \mathrm{s}$

Reynolds Number $=2.38 \mathrm{E}+03$ Critical Flow

Sauter Mean Diameter $=1.67 \mathrm{E}+01 \mu \mathrm{m}$

Optimum Slit Width $=1.77 \mathrm{E}-03$ in

Respirable Fraction $=4.59 \mathrm{E}-01$

Total Leak Rate $=2.05 \mathrm{E}+01 \mathrm{gpm}$

4.49E-05 m

Respirable Leak Rate $=9.41 \mathrm{E}+00 \mathrm{gpm}$

$1.29 \mathrm{E}-03 \mathrm{~m} 3 / \mathrm{s}$

$5.94 \mathrm{E}-04 \mathrm{~m} 3 / \mathrm{s}$

$1.43 \mathrm{E}+03 \mathrm{~g} / \mathrm{s}$

$6.57 \mathrm{E}+02 \mathrm{~g} / \mathrm{s}$ 
HNF-SD-WM-CN-065 Rev 2

SPRAY Version 3.0

May 3

Spray Leak Code

Produced by Radiological \& Toxicological Analysis

Westinghouse Hanford Company

Run Date $=03 / 02 / 97 /$

Run Time $=14: 52: 49.16$

INPUT ECHO:

c SPRAY Version 3 Input Deck

c unmitigated caustic spray - $12 \%$

c mode iflow iopt

$\begin{array}{lll}2 & 1 & \mathrm{~T}\end{array}$

$\mathrm{C}$

c MODEL OPTIONS:

$c$ mode $=1$ then orifice leak with friction assumed

2 then slit leak with friction assumed

iflow= 0 Reynold's number determines friction relation (i.e. laminar or turb.

$=1$ friction based on laminar relation

$=2$ friction based on turbulent relation

iopt $=T$ then optimal diameter search performed

C $=F$ then no optimal search

$\mathrm{C}$

C PARAMETER INPUT:

C

c Initial slit

c Width or Slit

c Orifice Dia.

c (in)

Length

Slit or

c

$\overline{1.00000 \mathrm{E}-0 \overline{3}}$

(in)

Orifice

Depth

(in)

C

c

c

c

c

C

c

C

C

$\overline{4.10000 \mathrm{E}+01} \overline{1.00000 \mathrm{E}-01}$

Absolute

Surface

Roughness

Contraction

Coefficient

Velocity

(in)

$\begin{array}{lll}0.00006 & \text { tube } 0.61 \\ 0.0018 & \text { steel } 1.00\end{array}$

and

Coefficient

Pressure

and

0.98 for sharp edge orifice

Differential

0.0102 iron 1.00

and

0.98 for rounded orifice

(psi)

$\overline{1.80000 E-03}$

$\overline{1.00000 E+00}$

0.82 for square edge orifice

$\overline{1.25000 \mathrm{E}+02}$

$1.80000 \mathrm{E}-03$

$8.20000 \mathrm{E}-01$ 


\begin{tabular}{|c|c|c|c|}
\hline $\begin{array}{l}\text { Fluid } \\
\text { Specific } \\
\text { Gravity }\end{array}$ & $\begin{array}{l}\text { Dynamic } \\
\text { Viscosity } \\
\text { (centi-poise) }\end{array}$ & $\begin{array}{l}\text { Respirable } \\
\text { Diameter } \\
(\mu \mathrm{m})\end{array}$ & $\begin{array}{l}\text { RR Fitting } \\
\text { Constant } \\
\text { (q) }\end{array}$ \\
\hline$\overline{1.11600 E+00}$ & $1.10000 E+00$ & $2.03000 E+01$ & $2.40000 \mathrm{E}+00$ \\
\hline
\end{tabular}

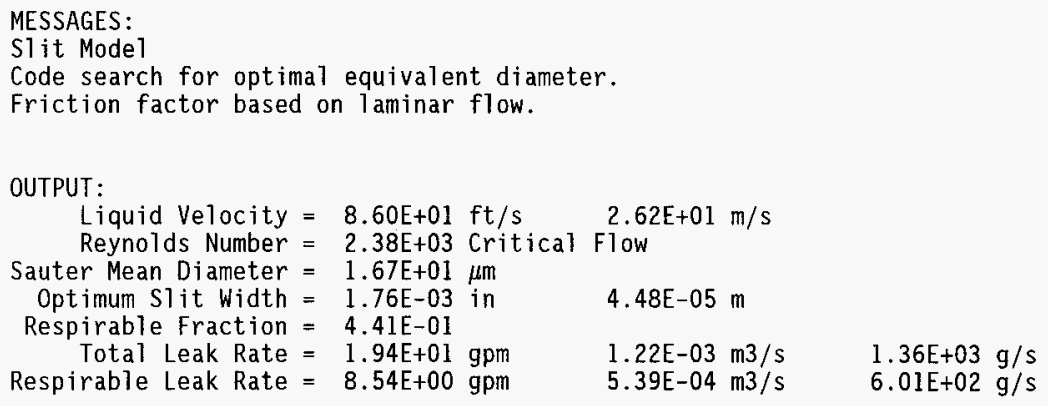


SPRAY Version 3.0

May 3

Spray Leak Code

Produced by Radiological \& Toxicological Analysis

Westinghouse Hanford Company

Run Date $=03 / 03 / 97 /$

Run Time $=07: 09: 42.52$

INPUT ECHO:

c SPRAY Version 3 Input Deck

c unmitigated caustic spray -

$13 \%$

c mode iflow iopt

$\begin{array}{lll}2 & 1 & \mathrm{~T}\end{array}$

C

c MODEL OPTIONS:

$c$ mode $=1$ then orifice leak with friction assumed

c $\quad 2$ then slit leak with friction assumed

c iflow $=0$ Reynold's number determines friction relation (i.e. laminar or turb.

c $\quad=1$ friction based on laminar relation

c $=2$ friction based on turbulent relation

$c$ iopt $=\mathrm{T}$ then optimal diameter search performed

$c=F$ then no optimal search

$C$

C PARAMETER INPUT:

$\mathrm{C}$

c Initial slit

c Orifice Dia.

c (in)

Length

S1it or

c

\section{$\overline{1.00000 E-03} \quad \overline{4.70000 E+01} \quad \overline{1.00000 E-01}$}

C

C

c

c

C

c

c

C

C

Absolute

Surface

Roughness

Contraction Coefficient

Velocity

(in)

Orifice

Depth

(in)

Pressure

0.00006 tube 0.61

and

Coefficient

Differential

0.0018 stee 1.00

and

0.98 for sharp edge orifice

(psi)

0.0102 iron 1.00 and

0.98 for rounded orifice

0.82 for square edge orifice

$\overline{1.25000 \mathrm{E}+02}$

$\overline{1.80000 E-03}$

$\overline{1.00000 E+00}$

$8.20000 \mathrm{E}-01$ 


$\begin{array}{lllll}\text { c Fluid } & \begin{array}{l}\text { Dynamic } \\ \text { C }\end{array} & \begin{array}{l}\text { Respirable } \\ \text { Siscosity } \\ \text { (centi-poise) }\end{array} & \begin{array}{l}\text { RR Fitting } \\ (\mu \mathrm{m})\end{array} & \begin{array}{l}\text { Constant } \\ (\mathrm{q})\end{array} \\ \mathrm{c} & \text { Gravity } & \overline{1.97000 \mathrm{E}+01} & \overline{2.40000 \mathrm{E}+00}\end{array}$

MESSAGES:

S1 it Mode 1

Code search for optimal equivalent diameter.

Friction factor based on laminar flow.

\section{OUTPUT:}

Liquid Velocity $=8.36 \mathrm{E}+01 \mathrm{ft} / \mathrm{s} \quad 2.55 \mathrm{E}+01 \mathrm{~m} / \mathrm{s}$

Reynolds Number $=2.03 E+03$ Critical Flow

Sauter Mean Diameter $=1.83 \mathrm{E}+01 \mu \mathrm{m}$

Optimum Slit Width $=1.81 \mathrm{E}-03$ in

$4.60 \mathrm{E}-05 \mathrm{~m}$

Respirable Fraction $=3.52 \mathrm{E}-01$

Tota1 Leak Rate $=2.22 \mathrm{E}+01 \mathrm{gpm}$

Respirable Leak Rate $=7.81 \mathrm{E}+00 \mathrm{gpm}$

$1.40 \mathrm{E}-03 \mathrm{~m} 3 / \mathrm{s}$

$4.92 \mathrm{E}-04 \mathrm{~m} 3 / \mathrm{s}$

$1.58 \mathrm{E}+03 \mathrm{~g} / \mathrm{s}$

$5.55 \mathrm{E}+02 \mathrm{~g} / \mathrm{s}$ 
SPRAY Version 3.0

May 3

Spray Leak Code

Produced by Radiological \& Toxicological Analysis

Westinghouse Hanford Company

Run Date $=03 / 02 / 97 /$

Run Time $=15: 09: 10.68$

INPUT ECHO:

c SPRAY Version 3 Input Deck

c unmitigated caustic spray -

c mode iflow iopt

$\mathrm{C}$

c MODEL OPTIONS:

$c$ mode $=1$ then orifice leak with friction assumed

c $\quad 2$ then slit leak with friction assumed

c iflow $=0$ Reynold's number determines friction relation (i.e. laminar or turb.

$\mathrm{c}=1$ friction based on laminar relation

c $=2$ friction based on turbulent relation

c iopt $=T$ then optimal diameter search performed

$c=F$ then no optimal search

c

c PARAMETER INPUT:

c Initial slit

c Width or

C Orifice Dia.

c (in)

C

$$
\overline{1.00000 E-03}
$$

S1 it

Length

(in)

$\overline{4.40000 E+01}$

Absolute

Surface

Roughness

(in)

Pressure

Differential

(psi)

$\overline{1.25000 \mathrm{E}+0 \overline{2}}$

Fluid

Specific

Gravity
0.00006 tube

0.0018 steel

0.0102 iron

$\overline{1.80000 E-03}$

Dynamic

Viscosity

(centi-poise)
STit or

Orifice

Depth

(in)

$\overline{1.00000 E-01}$

Contraction Coefficient

0.61 and

1.00 and

1.00 and

$\overline{1.00000 E+00}$

Respirable

Diameter

$(\mu \mathrm{m})$
Velocity

Coefficient

0.98 for sharp edge orifice

0.98 for rounded orifice

0.82 for square edge orifice

8.20000E-01

RR Fitting

Constant

(q) 
HNF-SD-WM-CN-065 Rev 2

\section{$1.14800 \mathrm{E}+00 \quad 1.30000 \mathrm{E}+00 \quad 1.88000 \mathrm{E}+01 \quad 2.40000 \mathrm{E}+00$}

MESSAGES:

S1 it Mode]

Code search for optimal equivalent diameter.

Friction factor based on laminar flow.

OUTPUT :

Liquid Velocity $=8.20 \mathrm{E}+0 \mathrm{ft} / \mathrm{s} \quad 2.50 \mathrm{E}+01 \mathrm{~m} / \mathrm{s}$

Reynolds Number $=1.98 \mathrm{E}+03$ Laminar Flow

Sauter Mean Diameter $=1.80 \mathrm{E}+01 \mu \mathrm{m}$

Optimum S1it Width $=1.76 \mathrm{E}-03$ in

Respirable Fraction $=3.32 \mathrm{E}-01$

Total Leak Rate $=1.98 \mathrm{E}+01 \mathrm{gpm}$

Respirable Leak Rate $=6.58 \mathrm{E}+00 \mathrm{gpm}$

$4.48 \mathrm{E}-05 \mathrm{~m}$

$1.25 \mathrm{E}-03 \mathrm{~m} 3 / \mathrm{s}$

$4.15 \mathrm{E}-04 \mathrm{~m} 3 / \mathrm{s}$

$1.44 \mathrm{E}+03 \mathrm{~g} / \mathrm{s}$

$4.76 \mathrm{E}+02 \mathrm{~g} / \mathrm{s}$ 
HNF-SD-WM-CN-065 Rev 2

SPRAY Version 3.0

May 3

Spray Leak Code

Produced by Radiological \& Toxicological Analysis

Westinghouse Hanford Company

Run Date $=03 / 02 / 97 /$

Run Time $=15: 10: 16.70$

INPUT ECHO:

c SPRAY Version 3 Input Deck

c unmitigated caustic spray - $20 \%$

c mode iflow jopt

$2 \quad 1 \quad T$

$\mathrm{C}$

c MODEL OPTIONS:

$c$ mode $=1$ then orifice leak with friction assumed

c 2 then slit leak with friction assumed

c iflow= 0 Reynold's number determines friction relation (i.e. laminar or turb.

c $\quad=1$ friction based on laminar relation

$c \quad=2$ friction based on turbulent relation

$\mathrm{c}$ iopt $=\mathrm{T}$ then optimal diameter search performed

$\mathrm{c}=\mathrm{F}$ then no optimal search

$\mathrm{C}$

c PARAMETER INPUT:

C

c Initial slit

c Width or Slit

c Orifice Dia.

c (in) (in)

C
$1.00000 \mathrm{E}-03$
$\overline{6.20000 E+01}$

Slit or

Orifice

Depth

(in)

C

C

c

c

c

c

c Differential

c (psi)

Absolute

Surface

Roughness

(in)

Contraction

Coefficient

0.00006 tube 0.61 and

Velocity

Coefficient

$\begin{array}{lll}0.0018 & \text { steel } 1.00 \\ 0.0102 & \text { iron } 1.00 & \text { and }\end{array}$

0.98 for sharp edge orifice

0.98 for rounded orifice

0.82 for square edge orifice

\section{$\overline{1.25000 \mathrm{E}+0 \overline{2}}$}

$\overline{1.80000 E-03}$

$1.00000 \mathrm{E}+00$

$8.20000 \mathrm{E}-01$

C 


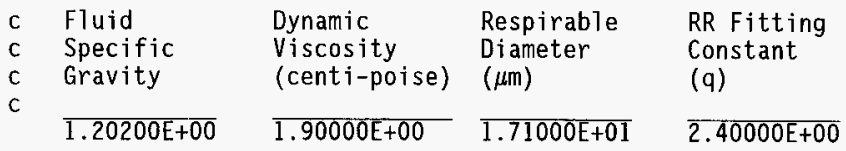

MESSAGES:

Slit Model

Code search for optimal equivalent diameter.

Friction factor based on laminar flow.

OUTPUT :

Liquid Velocity $=7.85 \mathrm{E}+01 \mathrm{ft} / \mathrm{s} \quad 2.39 \mathrm{E}+01 \mathrm{~m} / \mathrm{s}$

Reynolds Number $=1.55 \mathrm{E}+03$ Laminar Flow

Sauter Mean Diameter $=2.36 \mathrm{E}+01 \mu \mathrm{m}$

Optimum S1it Width $=2.02 \mathrm{E}-03$ in

Respirable Fraction $=1.53 \mathrm{E}-01$

Total Leak Rate $=3.06 \mathrm{E}+01 \mathrm{gpm}$

$5.13 \mathrm{E}-05 \mathrm{~m}$

Respirable Leak Rate $=4.70 \mathrm{E}+00 \mathrm{gpm}$

$1.93 \mathrm{E}-03 \mathrm{~m} 3 / \mathrm{s}$

$2.96 \mathrm{E}-04 \mathrm{~m} 3 / \mathrm{s}$

2. $32 \mathrm{E}+03 \mathrm{~g} / \mathrm{s}$

$3.56 \mathrm{E}+02 \mathrm{~g} / \mathrm{s}$ 
SPRAY Version 3.0

May 3

Spray Leak Code

Produced by Radiological \& Toxicological Analysis

Westinghouse Hanford Company

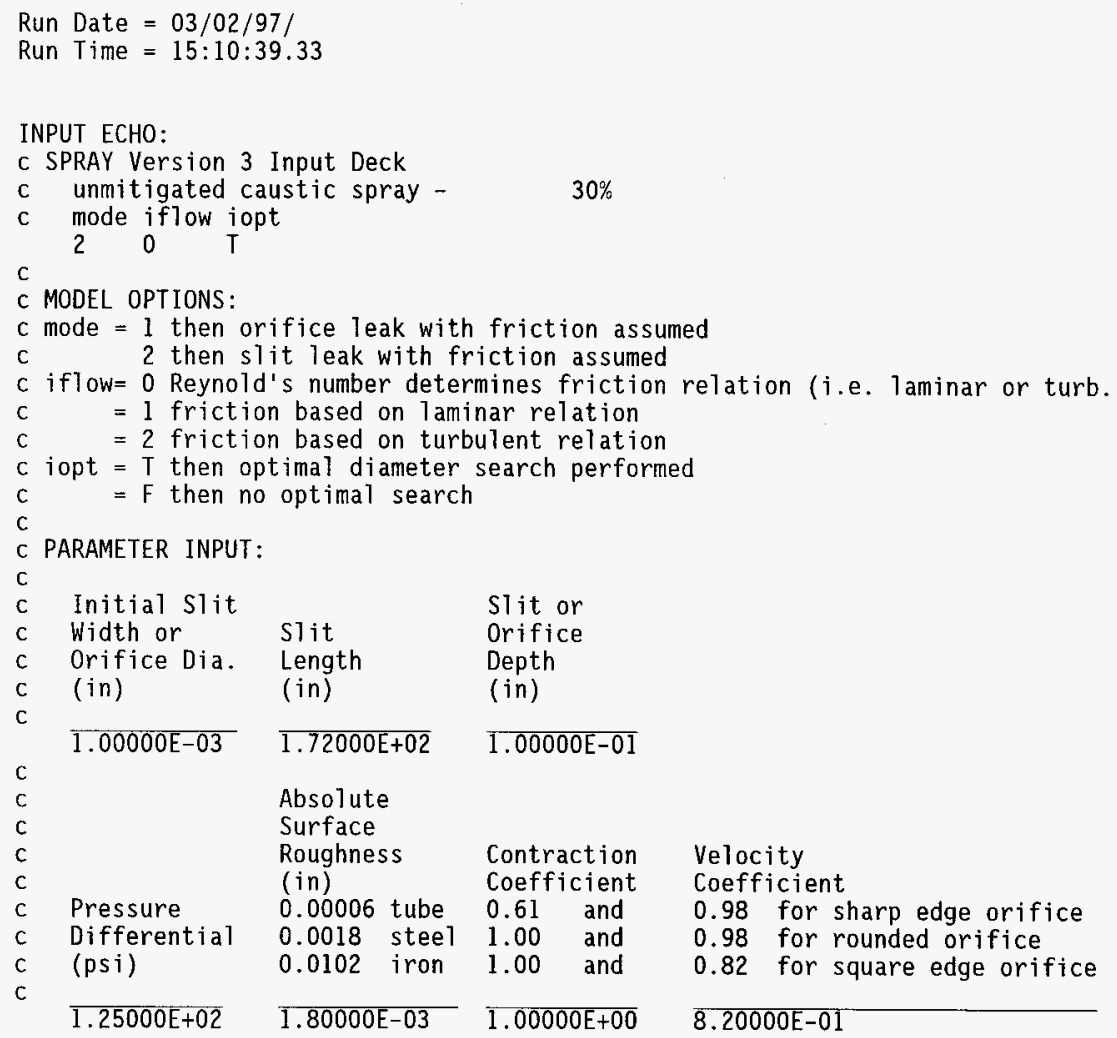




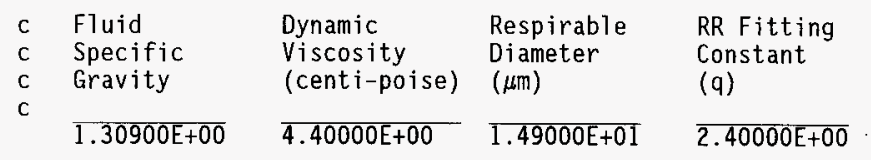

\section{MESSAGES:}

Slit Model

Code search for optimal equivalent diameter.

\section{OUTPUT:}

Liquid Velocity $=7.41 \mathrm{E}+01 \mathrm{ft} / \mathrm{s} \quad 2.26 \mathrm{E}+01 \mathrm{~m} / \mathrm{s}$

Reynolds Number $=9.97 \mathrm{E}+02$ Laminar Flow

Sauter Mean Diameter $=4.53 \mathrm{E}+01 \mu \mathrm{m}$

Optimum S1 it Width $=2.92 \mathrm{E}-03$ in

Respirable Fraction $=2.47 \mathrm{E}-02$

Total Leak Rate $=1.16 \mathrm{E}+02 \mathrm{gpm}$

Respirable Leak Rate $=2.87 \mathrm{E}+00 \mathrm{gpm}$

\section{$7.42 \mathrm{E}-05 \mathrm{~m}$}

$7.32 \mathrm{E}-03 \mathrm{~m} 3 / \mathrm{s}$

$1.81 \mathrm{E}-04 \mathrm{~m} 3 / \mathrm{s}$
$9.59 \mathrm{E}+03 \mathrm{~g} / \mathrm{s}$

$2.37 \mathrm{E}+02 \mathrm{~g} / \mathrm{s}$ 
SPRAY Version 3.0

May 3

Spray Leak Code

Produced by Radiological \& Toxicological Analysis

Westinghouse Hanford Company

Run Date $=03 / 03 / 97 /$

Run Time $=05: 38: 27.21$

INPUT ECHO:

c SPRAY Version 3 Input Deck

c unmitigated caustic spray - $\quad 40 \%$

c mode iflow iopt

$200 \quad T$

C

c MODEL OPTIONS:

c mode $=1$ then orifice leak with friction assumed

2 then slit leak with friction assumed

c iflow $=0$ Reynold's number determines friction relation (i.e. laminar or turb.

c $=1$ friction based on laminar relation

$c \quad=2$ friction based on turbulent relation

$c$ iopt $=T$ then optimal diameter search performed

c $=F$ then no optimal search

c

c PARAMETER INPUT:

C

c Initial slit

c Width or Slit

c Orifice Dia.

c

c

(in)

Length

Slit or

(in)

Orifice

Depth

(in)

$\overline{1.00000 \mathrm{E}-03} \quad \overline{3.96000 \mathrm{E}+02} \quad \overline{1.00000 \mathrm{E}-01}$

c

c

c

c

$\mathrm{C}$

c

c

c

c

Absolute

Surface

Roughness

(in)

Contraction

Coefficient

Pressure

0.00006 tube

0.61 and

Differential

0.0018

steel

1.00

and

0.0102 iron

1.00

and

$1.25000 \mathrm{E}+02$

$\overline{1.80000 E-03}$

$\overline{1.00000 E+00}$

Velocity

Coefficient

0.98 for sharp edge orifice

0.98 for rounded orifice

0.82 for square edge orifice 


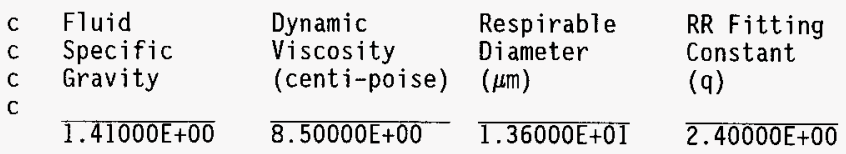

MESSAGES:

S1 it Model

Code search for optimal equivalent diameter.

OUTPUT:

Liquid Velocity $=7.12 \mathrm{E}+0 \mathrm{l} \mathrm{ft} / \mathrm{s} \quad 2.17 \mathrm{E}+01 \mathrm{~m} / \mathrm{s}$

Reynolds Number $=7.25 \mathrm{E}+02$ Laminar Flow

Sauter Mean Diameter $=7.65 \mathrm{E}+01 \mu \mathrm{m}$

0ptimum Slit Width $=3.97 \mathrm{E}-03$ in

Respirable Fraction $=5.70 \mathrm{E}-03$

Total Leak Rate $=3.49 \mathrm{E}+02 \mathrm{gpm}$

$1.01 \mathrm{E}-04 \mathrm{~m}$

Respirable Leak Rate $=1.99 \mathrm{E}+00 \mathrm{gpm}$

2. $20 \mathrm{E}-02 \mathrm{~m} 3 / \mathrm{s}$

$1.25 \mathrm{E}-04 \mathrm{~m} 3 / \mathrm{s}$

$3.10 \mathrm{E}+04 \mathrm{~g} / \mathrm{s}$

1. $77 \mathrm{E}+02 \mathrm{~g} / \mathrm{s}$ 
SPRAY Version 3.0

May 3

Spray Leak Code

Produced by Radiological \& Toxicological Analysis

Westinghouse Hanford Company

Run Date $=03 / 03 / 97 /$

Run Time $=07: 11: 56.81$

INPUT ECHO:

c SPRAY Version 3 Input Deck

c unmitigated caustic spray - $50 \%$

c mode iflow iopt

$200 \quad T$

$\mathrm{C}$

c MODEL OPTIONS:

$c$ mode $=1$ then orifice leak with friction assumed

c 2 then slit leak with friction assumed

c iflow 0 Reynold's number determines friction relation (i.e. laminar or turb.

c $\quad=1$ friction based on laminar relation

c $=2$ friction based on turbulent relation

$\mathrm{c}$ iopt $=\mathrm{T}$ then optimal diameter search performed

$c=F$ then no optimal search

$\mathrm{C}$

c PARAMETER INPUT:

$\mathrm{C}$

c Initial Slit

c Width or Slit

c Orifice Dia. Length

c (in)

C

\section{$\overline{1.00000 \mathrm{E}-03} \quad \overline{7.83000 \mathrm{E}+02} \quad \overline{1.00000 \mathrm{E}-01}$}

c

C

C

c

c

c

c

C

c

c
Absolute

Surface

Roughness

(in)

Pressure

0.00006 tube

Differential

(psi)

$\overline{1.25000 E+02}$
0.0018 steel

0.0102 iron

$\overline{1.80000 \mathrm{E}-03}$
Slit or

Orifice

Depth

(in)

Contraction

Coefficient

0.61 and

1.00 and

1.00 and

$1.00000 \mathrm{E}+00$
Velocity

Coefficient

0.98 for sharp edge orifice

0.98 for rounded orifice

0.82 for square edge orifice
$8.20000 \mathrm{E}-01$ 


\begin{tabular}{|c|c|c|c|c|}
\hline C & $\begin{array}{l}\text { Fluid } \\
\text { Specific } \\
\text { Gravity }\end{array}$ & $\begin{array}{l}\text { Dynamic } \\
\text { Viscosity } \\
\text { (centi-poise) }\end{array}$ & $\begin{array}{l}\text { Respirable } \\
\text { Diameter } \\
(\mu \mathrm{m})\end{array}$ & $\begin{array}{l}\text { RR Fitting } \\
\text { Constant } \\
\text { (q) }\end{array}$ \\
\hline & $1.50400 E+00$ & $1.43000 \mathrm{E}+01$ & $\overline{1.26000 \mathrm{E}+01}$ & $2.40000 \mathrm{E}+00$ \\
\hline
\end{tabular}

MESSAGES:

Slit Mode 7

Code search for optimal equivalent diameter.

OUTPUT:

Liquid Velocity $=6.89 \mathrm{E}+01 \mathrm{ft} / \mathrm{s} \quad 2.10 \mathrm{E}+01 \mathrm{~m} / \mathrm{s}$

Reynolds Number $=5.67 \mathrm{E}+02$ Laminar Flow

Sauter Mean Diameter $=1.16 \mathrm{E}+02 \mu \mathrm{m}$

Optimum Slit Width $=5.05 \mathrm{E}-03$ in

Respirable Fraction $=1.76 \mathrm{E}-03$

$\begin{aligned} \text { Total Leak Rate } & =8.49 \mathrm{E}+02 \mathrm{gpm} \\ \text { Respirable Leak Rate } & =1.49 \mathrm{E}+00 \mathrm{gpm}\end{aligned}$

$1.28 \mathrm{E}-04 \mathrm{~m}$

$5.36 \mathrm{E}-02 \mathrm{~m} 3 / \mathrm{s}$

$8.06 \mathrm{E}+04 \mathrm{~g} / \mathrm{s}$

$9.42 \mathrm{E}-05 \mathrm{~m} 3 / \mathrm{s} \quad 1.42 \mathrm{E}+02 \mathrm{~g} / \mathrm{s}$ 
HNF-SD-WM-CN-065 Rev 2

PEER AND HEDOP CHECKLISTS 
HNF-SD-WM-CN-065 Rev 2

\section{CHECKLIST FOR PEER REVIEW}

Document Reviewed: CONSEQUENCE ANALYSIS OF A NaOH SOLUTION SPRAY RELEASE DURING ADDITION TO WASTE TANK, D.A. Himes, 10/3/96

Scope of Review: entire document

Yes No NA

[ ] [ ] $\mathbb{X}] *$ Previous reviews complete and cover analysis, up to scope of this review, with no gaps.

[X] [ ] [ ] Problem completely defined.

$[X][][] \quad$ Accident scenarios developed in a clear and logical manner. Necessary assumptions explicitly stated and supported.

Computer codes and data files documented.

Data used in calculations explicitly stated in document.

Data checked for consistency with original source information as applicable.

[X] [ ] [ ] Mathematical derivations checked including dimensional consistency of resuits.

[X] [ ] [ ] Models appropriate and used within range of validity or use outside range of established validity justified.

[X] [ ] [ ] Hand calculations checked for errors. Spreadsheet results should be treated exactly the same as hand calculations.

[x] [ ] [ ] Software input correct and consistent with document reviewed.

[x] [ ] [ ] Software output consistent with input and with results reported in document reviewed.

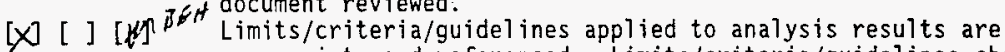
appropriate and referenced. Limits/criteria/guidelines checked against references.

$[X]$ [ ] [ ] Safety margins consistent with good engineering practices.

[X] [ ] [ ] Conclusions consistent with analytical results and applicable limits.

[X] [ ] [ ] Results and conclusions address all points required in the problem statement.

[ ] [ ] [ $]$ Format consistent with appropriate NRC Regulatory Guide or other standards

[ ] [X] * Review calculations, comments, and/or notes are attached.

[X] [ ] [ ] Document approved.

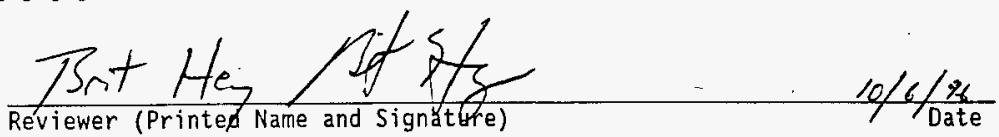

* Any calculations, comments, or notes generated as part of this review should be signed, dated and attached to this checklist. Such material should be labeled and recorded in such a manner as to be intelligible to a technically qualified third party. 


\section{HEDOP REVIEW CHECKLIST \\ for \\ Radiological and Nonradiological Release Calculations}

Document reviewed (include title or description of calculation, document number, author, and date, as applicable):

\section{CONSEQUENCE ANALYSIS OF A NaOH SOLUTION SPRAY RELEASE DURING ADDITION}

TO WASTE TANK, D.A. Himes, 10/3/96

Submitted by: D.A. Himes

Date Submitted:

Scope of Review: entire document

YES NO* N/A

[X]. [ ] [ ] 1. A detailed technical review and approval of the environmenta] transport and dose calculation portion of the analysis has been performed and documented.

L1 [ ] [ ] 2. Detailed technical review(s) and approval(s) of scenario and

[ ] [ ] [4 3. HEDOP-approved code(s) were used.

[1] [ ] [ $]$ 4. Receptor locations were selected according to HEDOP recommendations.

[4] : [ ] [ ] 5. Al] applicable environmental pathways and code options were.

[4] [ ] [ ] 6. Hanford site data were used.

[L] [ [ ] 7. Mode $]$ adjustments external to the computer program were justified and performed correctly.

[ ] [ ] [X 8. The analysis is consistent with HEDOP recommendations.

9. Supporting notes, calculations, comments, comment resolutions, or other information is attached. (Use the "Page 1 of $X$ " page numbering format and sign and date each added page.)

[ [ ]

10. Approval is granted on behalf of the Hanford Environmental Dose Overview Panel.

* All "NO" responses must be explained and use of nonstandard methods justified.

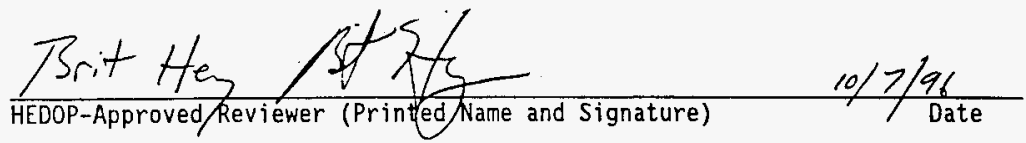

COMMENTS (add additional signed and dated pages if necessary): 


\section{CHECKLIST FOR PEER REVIEW}

Document Reviewed: HNF-SD-WM-CN-065, Rev. 2, CONSEQUENCE ANALYSIS OF A NaOH SOLUTION SPRAY RELEASE DURING ADDITION TO WASTE TANK, L. Lansing, 05/27/96

Scope of Review: Entire document

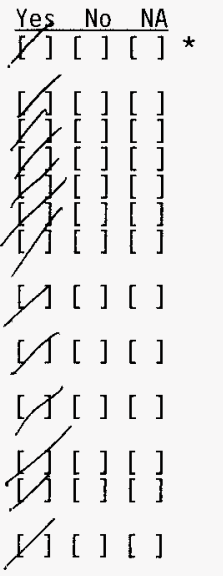

Previous reviews complete and cover analysis, up to scope of this review, with no gaps.

Problem completely defined.

Accident scenarios developed in a clear and logical manner.

Necessary assumptions explicitiy stated and supported.

Computer codes and data files documented.

Data used in calculations explicitly stated in document.

Data checked for consistency with original source information as applicable.

Mathematical derivations checked including dimensional consistency of results.

Models appropriate and used within range of validity or use outside range of established validity justified.

Hand calculations checked for errors. Spreadsheet results should be treated exactly the same as hand calculations.

Software input correct and consistent with document reviewed.

Software output consistent with input and with results reported in document reviewed.

Limits/criteria/guidelines applied to analysis results are appropriate and referenced. Limits/criteria/guidelines checked against references.

Yt [ ] [ [ ]

Safety margins consistent with good engineering practices.

Conclusions consistent with analytical results and applicable limits.

[A [ ] [ ] Results and conclusions address all points required in the problem statement.

L] [ ] [ ]

Format consistent with appropriate NRC Regulatory Guide or other standards

[ ]

Review calculations, comments, and/or notes are attached.

f] [ ] [ ] Document approved.

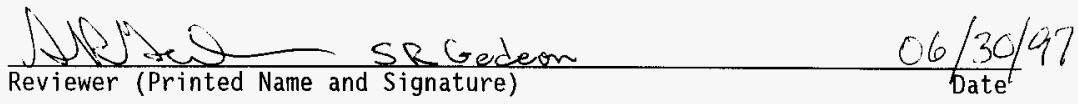

* Any calculations, comments, or notes generated as part of this review should be signed, dated and attached to this checklist. Such material should be labeled and recorded in such a manner as to be intelligible to a technically qualified third party. 


\section{DISTRIBUTION SHEET}

\begin{tabular}{|c|c|c|c|c|c|}
\hline \multirow{2}{*}{$\begin{array}{l}\text { To } \\
\text { Project } W-320 \\
\text { DE\&S Hanford, Inc. }\end{array}$} & \multirow{2}{*}{\multicolumn{3}{|c|}{$\begin{array}{l}\text { From } \\
\text { Fluor Daniel Northwest } \\
\text { Safety Analysis \& Risk Assessment }\end{array}$}} & \multicolumn{2}{|l|}{ Page 1 of 1} \\
\hline & & & & \multicolumn{2}{|c|}{ Date $06 / 27 / 97$} \\
\hline \multirow{2}{*}{\multicolumn{4}{|c|}{$\begin{array}{l}\text { Project Title/Work Order } \\
\text { HNF-SD-WM-CN-065, Rev } \\
\text { Solution Spray Releas }\end{array}$}} & \multicolumn{2}{|l|}{ EDT No. $\quad N / A$} \\
\hline & & & & \multicolumn{2}{|c|}{ ECN No. 609910} \\
\hline Name & MSIN & $\begin{array}{l}\text { Text } \\
\text { With All } \\
\text { Attach. }\end{array}$ & Text Only & $\begin{array}{l}\text { Attach./ } \\
\text { Appendix } \\
\text { Only }\end{array}$ & $\begin{array}{c}\text { EDT/ECN } \\
\text { Only }\end{array}$ \\
\hline $\begin{array}{l}\text { J.C. Conner } \\
\text { J.P. Harris } \\
\text { B.E. Hey } \\
\text { D.A. Himes } \\
\text { R.J. Van Vleet } \\
\text { S.R. Gedeon } \\
\text { Central Files } \\
\text { Docket Files } \\
\text { TWRS S\&L Files }\end{array}$ & \multicolumn{3}{|l|}{$\begin{array}{l}A 2-25 \\
\text { S2-48 } \\
A 3-34 \\
A 3-34 \\
A 3-34 \\
H 0-35 \\
A 3-88 \\
B 1-17 \\
A 2-26\end{array}$} & & \\
\hline
\end{tabular}

